\title{
Ortaöğretim Öğretmenlerinin Eğitimde Teknoloji Kullanımına Yönelik Tutumlarının İncelenmesi ${ }^{1}$
}

\section{Mehmet Alper Ardıç²}

\section{Type/Tür:}

Research/Araştırma

Received/Geliş Tarihi: June 4/ 4 Haziran 2020

Accepted/Kabul Tarihi: February 15/ 15 Şubat 2021

Pagenumbers/Sayfa No: 649-675

Corresponding

Author/İletişimden Sorumlu

Yazar: mardic@adiyaman.edu.tr

\section{$\checkmark$ iThenticate}

Thispaperwascheckedforplagiaris musingiThenticateduringtheprevi ewprocessandbeforepublication. / Bu çalışma ön inceleme sürecinde ve yayımlanmadan önce iThenticate yazılımı ile taranmıştır.

Copyright@ 2017 by Cumhuriyet University, Faculty of Education. Allrightsreserved.

\section{Öz}

$\mathrm{Bu}$ araştırmanın amacı ortaöğretim öğretmenlerinin eğitimde teknoloji kullanımına yönelik tutumlarını belirlemektir. Katılımcıların kolay ulaşılabilir örneklem metoduyla, gönüllülük esasına göre belirlendiği araştırmada Adıyaman ilindeki çeşitli lise türlerinde görev yapan, farklı branşlardaki 378 ortaöğretim öğretmeni katılımcı olarak yer almıştır. Araştırmada nicel araştırma yöntemlerinden olan kesitsel tarama modelinden yararlanılmıştır. Araştırmada veri toplama aracı olarak iki kısımdan oluşan bir formdan yararlanılmışır. Formun ilk kısmında öğretmenlerin demografik bilgileri, derslerinde teknolojik araçları kullanma sıklıkları, kullandıkları teknolojik araçlar ve bilgisayar programlarıyla ilgili sorular yer almaktadır. Formun ikinci kısımda ise Teknolojiye Yönelik Tutum Ölçeğine (TYTÖ) yer verilmiştir. Beşli likert tipinde olan TYTÖ, beş faktörden ve 19 maddeden oluşmaktadır. Araştırmada TYTÖ'nün Cronbach's Alpha güvenirlik katsayısı 0.83 olarak hesaplanmıştır. Araştırmada elde edilen veriler çoklu varyans analizi kullanılarak incelenmiştir. Gerçekleştirilen analizler sonucunda ortaöğretim öğretmenlerinin teknolojiye yönelik tutumlarının TYTÖ’nün genelinde ve faktörlerinin tamamında "olumlu" düzeyde olduğu anlaşılmıştır. Ayrıca ortaöğretim öğretmelerinin teknolojiye yönelik tutumlarının cinsiyetlerine, hizmet sürelerine, eğitim düzeylerine ve daha önce derslerinde teknoloji kullanımı hakkında eğitim almış olma durumlarına göre anlamlı farklılık göstermediği anlaşılmıştır. Öte yandan ortaöğretim öğretmenlerinin teknolojiye yönelik tutumlarının yaşlarına, branşlarına, çalıştıkları okul ile mezunu oldukları fakülte türlerine, derslerinde teknolojik araçlardan yararlanma sıkılıklarına ve bu derslerde kullandıkları teknolojik araç veya bilgisayar yazılım çeşitliliğine göre TYTÖ genelinde veya çeşitli faktörlerinde anlamlı farklılıklar gösterdiği anlaşılmıştır.

Anahtar Kelimeler: Eğitimde teknoloji kullanımı, FATïH Projesi, ortaöğretim öğretmenleri, öğretmen tutumu, teknolojiye yönelik tutum.

Suggested APA Citation/Önerilen APA Atıf Biçimi:

Ardıç, M. A. (2021). Ortaöğretim öğretmenlerinin eğitimde teknoloji kullanımına yönelik tutumlarının incelenmesi. Cumhuriyet International Journal of Education, 10(2), 649-675. http://dx.doi.org/10.30703/cije.748219

\section{Examination of Secondary Education Teachers' Attitudes towards Technology Use in Education}

\footnotetext{
${ }^{1} \mathrm{Bu}$ araştırma bulgularının bir bölümü 4. Uluslararası Türk Bilgisayar ve Matematik Eğitimi Sempozyumu'nda sözlü bildiri olarak sunulmuştur.

2 Araştırma Görevlisi Doktor, Adıyaman Üniversitesi, Fen-Edebiyat Fakültesi/Matematik Bölümü, Adıyaman/Türkiye

Research Assistant Doctor, Adiyaman University, Faculty of Arts and Sciences/Department of Mathematics

Adıyaman/Turkey

e-mail: mardic@adiyaman.edu.tr ORCID ID: orcid.org/ 0000-0001-9816-4422
} 


\begin{abstract}
This research aims to determine the attitudes of secondary education teachers towards the use of technology in education. The participants were determined on a voluntary basis using the convenience sampling method. 378 teachers of different branches working at various high schools in Adryaman province participated. The descriptive study, one of the quantitative research methods, was utilized in the study. In the research, a form consisting of two sections was used as the data collection tool. In the first section questions related to the demographic information of the teachers, frequency of their using the technological tools in lessons, and techological devices and softwares they utilize. The Scale of Attitude towards Technology (SATT) takes part in the second section. As a five-point Likert scale, SATT consists of five factors and 19 items. Cronbach's Alpha of SATT was calculated as 0.83 . The obtained data were examined by multiple variance analysis. The results of the analyses revealed that the attitudes of teachers were at a "positive" level throughout SATT and at all of its factors. It was also seen that the attitudes of teachers do not differ significantly based on their gender, duration of service, education levels, status of previous education on the use of technology in their lessons. Besides, it was understood that the attitudes of teachers differ significantly across SATT or various factors based on their ages, branches, type of school they work and the faculty they graduated, frequency of using technological tools in courses and the variety of the devices or softwares used.
\end{abstract}

Keywords: Using technology in education, FATIHH Project, Secondary education teachers, Teacher attitude, Attitude towards Technology.

\title{
Giriş
}

Yazının icadıyla sözlü anlatımdan yazılı anlatıma geçerek bilginin yayılma ve depolanma serüveninde çağ atlayan insanlık bugünlerde internet, bulut bilişim sistemleri gibi teknolojiler sayesinde bilgiyi hiç olmadığı kadar kolay iletmekte, depolamakta ve dolayısıyla da üretmektedir. Günümüzde katlanarak artan bilgi birikiminin ve teknolojik ilerlemelerin ürünü olan yapay zeka gibi enstrümanların üretim sahalarına girmesiyle dördüncü sanayi devriminin gerçekleşmesine tanık olmaktayız. Sanayi devriminden bu yana, temelde üretim alanında ihtiyaç duyulan nitelikli insan gücünün yetiştirilmesine yönelik şekillenen modern eğitim-öğretim faaliyetlerinin, eşiğinde bulunduğumuz yeni dönemin gereksinimlerine göre değişmesi kaçınılmazdır. Bu değişimin, üretim süreçlerini etkileyen teknolojinin eğitim-öğretim faaliyetleriyle bütünleşmesi sonucunda gerçekleşeceği söylenebilir. Nitekim eğitimde teknolojinin kullanılmasıyla nitelikli bilgiye erişim kolaylaşmış ve etkileşimli hale gelmiştir. Fletcher (2003) bu sayede öğretim sürecinde zaman ve maliyetlerden tasarruf sağlanarak bütün öğrenciler için bireysel farklılıkların dikkate alındığı daha etkili bir eğitimin gerçekleştirilebileceğini ifade etmektedir.

Eğitimde teknoloji kullanımında karşılaşılan engeller hakkında gerçekleştirilen çalışmalar incelendiğinde bu engellerin iki düzeyden oluştukları anlaşılmaktadır (Ertmer, 1999). Bunlar dişsal ve içsel engellerdir. Öğretim sürecinde ihtiyaç duyulan donanım ve yazılımlara ulaşılamaması, öğretim planlarının uygun olmaması, gerekli teknik ve idari desteğin alınamaması gibi öğretmenden bağımsız olan engeller dişsal engellerdir. İçsel engeller ise öğretmenlerin kendilerine ve öğretme-öğrenme faaliyetlerine yönelik tutum ve inançları olarak özetlenebilir. Öğretmenlerin teknolojiye yönelik tutumları (TYT), özgüvenleri, mevcut öğretme ve sınıf rutinlerine yönelik inançları, değişime olan inançları içsel engellere örnek olarak 
verilebilir. Ertmer (1999) eğitimde teknoloji kullanımına yönelik içsel engellerin aşılmasının dişsal engellerin aşılmasından daha zor olduğunu ifade etmektedir. Dışsal engellerin genel manada öğretmenlerden bağımsız olduğu düşünüldüğünde bu engellerin aşılması için asıl çabayı politika yapıcıların ve eğitim yöneticilerinin göstermesi gerektiği söylenebilir. Bu bağlamda son otuz yıldır birçok hükümet okullardaki teknolojik imkânları iyileştirmek için kayda değer düzeyde para ve insan kaynağı sarf etmekte ve dişsal engelleri aşmaya çalışmaktadır (Cattagni ve Farris, 2001; Ertmer, Ottenbreit-Leftwich, Sadik, Sendurur ve Sendurur, 2012; Göktaş, Gedik ve Baydaş, 2013). Türkiye'de 2011 yılında başlanan Eğitimde Fırsatları Arttırma ve Teknolojiyi İyileştirme Hareketi (FATİH) Projesi söz konusu çalışmalara örnek olarak verilebilir. Eğitimde FATİH Projesiyle dersliklere akıllı (etkileşimli) tahta yerleştirilip, geniş bant internet erişimi sağlanmış ayrıca birçok okulda öğretmen ve öğrencilere tablet bilgisayar dağıtımı da yapılmıştır. Projede sınıfların teknik altyapıları geliştirilerek eğitim-öğretim faaliyetlerinde teknolojinin etkin kullanımı sağlanıp öğrenme-öğretme sürecinde daha fazla duyu organına hitap edilmesi ve öğretimde fırsat eşitliğinin sağlanması hedeflenmektedir. Ayrıca öğretmenlerin derslerinde teknolojik araçlardan yaralanması ve e-içerikler oluşturması için proje bünyesinde hizmet içi eğitimler düzenlemiş ve web platformları oluşturulmuştur (Milli Eğitim Bakanlığı [MEB], 2020). Araştırmalara göre çok sayıda ülkede gerçekleştirilen FATİH benzeri projeler sayesinde derslerde teknoloji kullanımına yönelik dişsal engellerin büyük oranda aşıldığı fakat bu süreçte içsel engellerin hala belirleyici düzeyde etkisinin olduğu anlaş1lmaktadır (Ertmer vd., 2012; Göktaş vd., 2013; Ottenbreit-Leftwich, Liao, Sadik ve Ertmer, 2018). Bu yönüyle eğitimde teknolojinin etkin kullanımının sağlanabilmesi için öğretmenlerin tutumlarının belirlenmesi önem arz etmektedir. Eğitimde teknoloji kullanımına yönelik olumsuz tutum gibi içsel engeller her ne kadar soyut veya fenomonolojik görünse de temelde davranışlarla ilişkilidir (Oskamp ve Schultz, 2005). Tutum kısaca, "bir bireye atfedilen ve onun bir psikolojik obje ile ilgili düşünce, duygu ve davranışlarını düzenli bir biçimde oluşturan eğilim olarak ifade edilebilir" (Kağıtçıbaşı, 1999). Bir kişi, nesne, durum veya olaya yönelik tutum bilişsel, duygusal ve davranışsal olmak üzere üç boyutlu bir yapıdan oluşmaktadır dolayısıyla da bilişsel, duygusal ve davranışsal tepkilerle ifade edilmektedir (Oskamp ve Schultz, 2005). Bu yönüyle bireyin belli bir konuya yönelik tutumu; bu konuya ilişkin düşüncelerini, duygularını veya inançlarını ifade ettiği görüşleri ve davranışları ele alınarak anlaşılabilir. Bu durum öğretmenlerin eğitimde teknoloji kullanımına yönelik tutumlarını ölçek yardımıyla belirlemeyi mümkün kılmaktadır.

Buabeng-Andoh (2012)'ye göre öğretmenlerin TYT'leri olumlu olduğunda, öğretmenler teknolojinin öğrenme-öğretme süreçlerinde kullanılmasına kolayca adapte olup teknolojiyi sınıf uygulamalarına entegre edebildikleri anlaşılmaktadır. Ayrıca birçok çalışmada TYT'nin, teknolojinin derslerde etkin kullanımında önemli yeri olan teknolojik pedagojik alan bilgisi yeterliliklerinin yordanmasına ve geliştirilmesine olumlu etkisi olduğu sonucuna varılmıştır (Albayrak-Sarı, Canbazoğlu-Bilici, Baran ve Özbay, 2016; Buabeng-Andoh, 2012; Çelik ve Yeşilyurt, 2013; Kalemoğlu Varol, 2015; Yulisman, Widodo, Riandi ve Nurina, 2019). Her ne kadar Türkiye'de gerçekleştirilen çalışmalarda katılımcıların TYT'lerinin "yüksek" olduğu tespit edilse de (Birkollu, Yücesoy, Bağlama ve Kanbul, 2017; Çakır ve 
Oktay, 2013; Kayalar, 2018; Paşa, Bolat ve Karataş, 2015; Üstün ve Akman, 2015) bu çalışmalarının büyük çoğunluğunun katılımcıların öğretmen adayları olduğu anlaşılmaktadır. Ayrıca ortaöğretim öğretmenlerinin TYT'leri özelinde yapılan literatür taramasında yeterli çalışmaya rastlanmamıştır. Geleceğin öğretmenlerinin TYT'lerinin yüksek olması ileride gerçekleştirecekleri öğretim faaliyetleri için önem arz etmektedir. Fakat öğretim faaliyetlerinde kilit roldeki öğretmenlerin yer aldığ çalışmalardaki azlık ise mevcut durumu anlamayı oldukça güçleştirmektedir (Bahar, İçli ve Gülaçtı, 2010; Birgin, Uzun ve Akar, 2020; İspir, Furkan ve Çitil, 2007; Paşa vd., 2015). Ayrıca söz konusu çalışmaların çoğunlukla fen ve matematik öğretimi alanlarında gerçekleştirilmiş olması da farklı branşlardaki ortaöğretim öğretmenlerinin TYT'leriyle ilgili mevcut durumu bütüncül bir bakışla anlamayı güçleştirmektedir (Birgin vd., 2020; İspir vd., 2007; Paşa vd., 2015). Öte yandan literatürde gözlemlenen diğer bir durum ise çalışmaların tamamına yakınında katılımcıların demografik bilgileri üzerinden incelemeler yapılmış fakat genel durumu ortaya koyacak düzeyde tutarlı ana akım sonuçların elde edilememiş olmasıdır. Cinsiyet değişkenine göre yapılan TYT incelemeleri buna örnek olarak verilebilir. Bazı çalışmalarda kadınlar (Bisgin, 2014; Çakır ve Oktay, 2013) ya da erkekler (Birkollu vd., 2017; Şahin ve Naml1, 2019) lehine farklılıklar gözlemlenirken bazılarında ise herhangi bir anlamlı farklılığa rastlanmamıştır (Dursun, Tozoğlu, Bayraktar, Çingöz ve Tozoğlu, 2017; Fındıkoğlu, Alcı ve Karataş, 2015; Kayalar, 2018; Şimşek ve Yıldırım, 2016). Bu durumun yaş ve mesleki tecrübe gibi farklı demografik değişkenler için de benzer olduğu söylenebilir. Hali hazırdaki durum dikkate alındığında ortaöğretim öğretmenlerinin TYT'lerinin demografik değişkenler yönünden incelenmesinin, literatürdeki belirsizliği giderme hususunda katk1 sağlayabileceği düşünülmektedir. Yine bu sayede öğretmenlerin derslerde teknoloji kullanımına yönelik ihtiyaç duyduğu hizmet içi eğitimi gibi faaliyetlerin planlamasında demografik farklılıklara özgü gereksinimlerin belirlenebileceği düşünülmektedir.

Kısacası, eğitim-öğretim faaliyetlerinde teknoloji kullanımının istenilen düzey ve şekilde gerçekleştirilebilmesi için mümkün olduğunca dışsal ve içsel engellerden arındırılmış uygulamalara ihtiyaç duyulmaktadır. Özelikle dışsal engellerin FATİH gibi projeler sayesinde günümüzde büyük ölçüde aşıldığı veya aşılmakta olduğu kabul edilebilir. Bu bağlamda öğretmenlerin teknolojiye yönelik olumsuz tutumları gibi içsel engeller ön plana çıkmaktadır. Ortaya konan bu durumu ortaöğretim öğretmenleri özelinde bütüncül bir bakış açısıyla ele alan araştırmalara literatürde rastlanmamış olmasından dolayı, bu çalışmada ortaöğretim öğretmenlerinin TYT'leri araştırılmıştır. Araştırmada elde edilen verilerin öğretmenlere, araştırmacılara ve politika yapıcılara eğitim-öğretim faaliyetlerinde teknoloji kullanımına yönelik harcayacakları zaman, para ve insan kaynağını daha etkili kullanmaları hakkında fikir verebileceği düşünülmektedir.

\section{Araştırma Soruları}

Ortaöğretim öğretmenlerinin eğitimde teknoloji kullanımına yönelik tutumlarının belirlenmeye çalışıldığı bu araştırmada şu sorulara cevap aranmıştır:

1. Öğretmenlerin TYT'leri ne düzeydedir?

2. Öğretmenlerin TYT'leri cinsiyetlerine göre farklılık göstermekte midir? 
3. Öğretmenlerin TYT'leri yaşlarına veya hizmet sürelerine göre farklılık göstermekte midir?

4. Öğretmenlerin TYT'leri branşlarına veya çalıştıkları okul türlerine göre farklılık göstermekte midir?

5. Öğretmenlerin TYT’leri mezunu oldukları fakülte türüne veya eğitim düzeylerine göre farklılık göstermekte midir?

6. Öğretmenlerin TYT'leri derslerinde teknoloji kullanımı hakkında eğitim almalarına göre farklılık göstermekte midir?

7. Öğretmenlerin TYT'leri derslerinde teknolojik araçları kullanma sıklıklarına göre farklılık göstermekte midir?

8. Öğretmenlerin TYT'leri derslerinde kullandıkları teknolojik araç veya bilgisayar yazılımı çeşitliliğine göre farklılık göstermekte midir?

\section{Yöntem}

Öğretmenlerin TYT'lerinin incelendiği bu araştırmada nicel araştırma yöntemlerinden kesitsel tarama modeli kullanılmıştır. Büyüköztürk, Kılıç, Akgün, Karadeniz ve Demirel (2010)'a göre tarama çalışmaları diğer araştırma türlerine nazaran daha büyük örneklemlerle yapılan, katılımcıların bir olay ya da konuya yönelik yetenek, tutum, görüş vb. özelliklerinin belirlendiği araştırmalardır.

\section{Çalışma Grubu}

Çalışma 2018-2019 eğitim-öğretim yılında Adıyaman ilindeki çeşitli lise türlerinde görev yapan gönüllü öğretmenlerin katılımıyla gerçekleştirilmiştir. Katılımcıların belirlenmesinde kolay ulaşılabilir örneklem yönteminden yararlanılmıştır. Yıldırım ve Şimşek (2008)'e göre kolay ulaşılabilir örneklemler göreli olarak daha az maliyetlidir ve bazı araştırmacılar için pratik ve kolay olarak algılanabilir. Kolay ulaşılabilir örneklem, yakın ve erişilmesi kolay olan durumun seçilmesidir. Çalışmanın başlangıçta 574 ortaöğretim öğretmenine ulaşılmıştır. Söz konusu öğretmenlerin 402 tanesi araştırma için gönüllü olmuştur. Veri toplama formunun uygulanmasından sonra yapilan ilk incelmede 378 tanesine ait formun eksiksiz ve tutarlı olarak doldurulduğu anlaşılmıştır. Bu bağlamda araştırmada 378 öğretmene ait verilerin incelenmesine karar verilmiştir. Katılımcılara ait bazı demografik bilgiler Tablo 1'deki gibidir.

Araştırmada "Yabancı Dil" branşıyla Arapça, Almanca ve İngilizce; "Fen" branşıyla biyoloji (34 kişi), kimya (13 kişi) ve fizik (22 kişi); "Sosyal" branşıyla coğrafya (21 kişi) ve tarih (19 kişi); "Sosyal Meslek" branşıyla imam hatip lisesi meslek dersleri (32 kişi), ticaret lisesi meslek dersleri (6 kişi) vb., "Teknik Meslek" branşıyla teknik lise meslek dersleri (26 kişi), bilgisayar ve öğretim teknolojileri (5 kişi) öğretmenlerine ait veriler beraber değerlendirilmiştir. Ayrıca "Diğer" kodlamasıyla da sınırlı sayıda öğretmenin olduğu müzik (4 kişi) ve resim (2 kişi) gibi branşlardaki katılımcıların verileri birlikte ele alınmıştır. 
Tablo 1

Katılımcıların Bazı Demografik Bilgileri

\begin{tabular}{clcc}
\hline & & $\mathbf{N}$ & $\mathbf{\%}$ \\
\hline \multirow{2}{*}{ Cinsiyet } & Kadın & 118 & $\% 31$ \\
& Erkek & 260 & $\% 69$ \\
\hline \multirow{3}{*}{ Yaş } & $21-25$ & 7 & $\% 1.9$ \\
& $26-30$ & 42 & $\% 11.1$ \\
& $31-35$ & 57 & $\% 15.1$ \\
& $36-40$ & 126 & $\% 33.3$ \\
& $41+$ & 146 & $\% 38.6$ \\
\hline \multirow{3}{*}{ Hizmet süreleri } & $1-5$ & 54 & $\% 14.3$ \\
& $6-10$ & 47 & $\% 12.4$ \\
& $11-15$ & 82 & $\% 21.7$ \\
& $16-20$ & 112 & $\% 29.6$ \\
& $21+$ & 83 & $\% 22$ \\
\hline \multirow{3}{*}{ Branş } & Fen & 69 & $\% 18.3$ \\
& Matematik & 57 & $\% 15.1$ \\
& Sosyal Meslek & 52 & $\% 13.8$ \\
& Türk Dili ve Edebiyatı & 50 & $\% 13.2$ \\
& Yabanci Dil & 47 & $\% 12.4$ \\
& Sosyal & 40 & $\% 10.6$ \\
& Diğer & 32 & $\% 8.5$ \\
& Teknik Meslek & 31 & $\% 8.2$ \\
\hline
\end{tabular}

\section{Veri Toplama Aracı}

Araştırmada veri toplama aracı olarak iki kısımdan oluşan bir formdan yararlanılmıştır. Formun ilk kısmında öğretmenlerin demografik bilgileri, derslerinde teknolojik araçları kullanma sıklıkları, kullandıkları donanımlar ve yazılımlarla ilgili sorular yer almaktadır. İkinci kısımda ise Teknolojiye Yönelik Tutum Ölçeği'ne (TYTÖ) yer verilmiştir (Yavuz, 2005).

Beşli likert tipinde olan TYTÖ, beş faktörden ve 19 maddeden oluşmaktadır. $\mathrm{Bu}$ faktörler "teknolojik araçların eğitim alanında kullanılmama durumu" (1.Faktör, 5 madde) , "teknolojik araçların eğitim alanında kullanılma durumu" (2.Faktör, 4 madde), "teknolojinin eğitim yaşamına etkileri" (3.Faktör, 4 madde), "teknolojik araçların kullanımının öğretilmesi" (4.Faktör, 4 madde) ve "teknolojik araçların değerlendirilmesi" (5.Faktör, 2 madde) şeklindedir. TYTÖ'de yer alan maddelerin 6 tanesi olumsuz iken geriye kalan 13 madde olumludur. Söz konusu olumsuz maddelere verilen yanıtlar tersten puanlanarak araştırmaya dahil edilmiştir. TYTÖ'yü oluşturan 19 madde için ayrı ayrı hesaplanan madde ayırt ediciliği ve madde güçlüğü toplam korelasyonları 0.24 ile 0.68 arasında değişmektedir. Ölçeğin Cronbach's Alpha güvenirlik katsayısı Yavuz (2005) tarafından 0.87 olarak hesaplanmışken bu çalışmada 0.83 olarak hesaplanmıştır.

\section{Verilerin Analizi}

Çalışmada elde edilen verilerin incelenmesinde tek faktörlü çoklu varyans analizi (MANOVA) kullanılmıştır. Analiz aşamasında MANOVA uygulanmadan önce verilerin gerekli ön şartlara uygunluğu kontrol edilmiş ve anlamlı bir ihlale rastlanmamıştır. Araştırmada bağımlı değişkenlerde gözlenen farkların kaynağının belirlenmesi amacıyla izleme testi olarak, her bir bağımlı değişken için varyans 
analizi (ANOVA) uygulanmıştır. MANOVA sonuçlarının manidar olduğu durumlarda izleme testlerinin değerlendirilmesinde $\alpha=.05$ anlamlılık düzeyi, anlamlı olmadığı durumlarda ise Bonferroni düzeltmesi yapılarak $\alpha=.008$ anlamlılık düzeyi kullanılmıştır. Ayrıca ANOVA'lar neticesinde gözlemlenen anlamlı farkların hangi bağımsız değişkenler arasında olduğunun anlaşılması için Hochberg'in GT2 testi kullanılmıştır. Field (2009)'a göre söz konusu test gruplar arasındaki katılımcı sayısının büyük oranda birbirinden farklı olduğu durumların karşılaştırılmasında diğer post hoc. testlerine göre istatistiksel olarak daha güçlü ve Tip I hata oranını kontrol altında tutmada daha başarılıdır.

\section{Bulgular}

Araştırmadan elde edilen bulgular araştırma soruları doğrultusunda analiz edilerek tablolar halinde sunulmuştur.

\section{Öğretmenlerin TYT'leri ne düzeydedir?}

Gerçekleştirilen betimsel analiz sonucunda öğretmenlerin TYTÖ genel ortalamasının $\overline{\mathrm{X}}=3.94$ olduğu ve teknolojiye yönelik "olumlu" tutuma sahip oldukları görülmüştür (Tablo 2). Ayrıca söz konusu durumun ölçeğin bütün faktörleri için aynı olduğu anlaşılmıştır.

Tablo 2

Öğretmenlerin TYT'leri

\begin{tabular}{lcccl}
\hline TYTÖ Faktörleri & $\mathbf{N}$ & $\overline{\mathbf{X}}$ & $\mathbf{S S}$ & Tutum \\
\hline 1.Faktör & 378 & 4.11 & 0.77 & Olumlu \\
2.Faktör & 378 & 3.82 & 0.75 & Olumlu \\
3.Faktör & 378 & 3.83 & 0.63 & Olumlu \\
4.Faktör & 378 & 3.91 & 0.75 & Olumlu \\
5.Faktör & 378 & 4.00 & 0.80 & Olumlu \\
TYTÖ & 378 & 3.94 & 0.51 & Olumlu \\
\hline
\end{tabular}

Öğretmenlerin TYT'leri cinsiyetlerine göre farklılık göstermekte midir?

Öğretmenlerinin cinsiyetlerine göre TYTÖ ortalamaları Tablo 3'teki gibidir.

Tablo 3

Öğretmenlerin Cinsiyetlerine Göre TYTÖ Puanları

\begin{tabular}{cccccccccccccc}
\hline \multirow{2}{*}{ Cin. } & & \multicolumn{3}{c}{ 1.Faktör } & \multicolumn{2}{c}{ 2.Faktör } & \multicolumn{2}{c}{ 3.Faktör } & \multicolumn{2}{c}{ 4.Faktör } & \multicolumn{2}{c}{ 5.Faktör } & \multicolumn{2}{c}{ TYTÖ } \\
\cline { 2 - 15 } & $\mathbf{N}$ & $\overline{\mathbf{X}}$ & SS & $\overline{\mathbf{X}}$ & SS & $\overline{\mathbf{X}}$ & SS & $\overline{\mathbf{X}}$ & SS & $\overline{\mathbf{X}}$ & SS & $\overline{\mathbf{X}}$ & SS \\
\hline $\mathrm{K}$ & 118 & 4.21 & 0.73 & 3.86 & 0.78 & 3.81 & 0.67 & 3.81 & 0.79 & 3.97 & 0.88 & 3.94 & 0.55 \\
$\mathrm{E}$ & 260 & 4.06 & 0.78 & 3.80 & 0.74 & 3.84 & 0.61 & 3.96 & 0.72 & 4.01 & 0.77 & 3.93 & 0.49 \\
\hline
\end{tabular}

K: Kadın, E: Erkek

MANOVA sonucunda öğretmenlerinin TYT’lerinin cinsiyetlerine göre anlaml farklılık göstermediği anlaşılmıştır (Pillai's Trace V=.030, F(5,372)= 2.285). Benzer şekilde ANOVA'lar sonucunda da (Tablo 4) öğretmenlerin TYT'lerinde cinsiyetlerine göre anlamlı bir farklılık olmadığı anlaşılmıştır ( $p>.008)$. 
Tablo 4

Öğretmenlerin Cinsiyetlerine Göre ANOVA Sonuçları

\begin{tabular}{|c|c|c|c|c|c|c|c|}
\hline \multicolumn{2}{|c|}{ Varyans } & Kareler Toplamı & sd & Kareler Ortalaması & $\mathbf{F}$ & $\mathbf{p}^{*}$ & Kismi $\eta^{2}$ \\
\hline \multirow{3}{*}{ 1.Faktör } & G.aras1 & 1.895 & 1 & 1.895 & 3.250 & .072 & .009 \\
\hline & G.içi & 219.218 & 376 & .583 & & & \\
\hline & Toplam & 221.113 & 377 & & & & \\
\hline \multirow{3}{*}{ 2.Faktör } & G.arası & .335 & 1 & .335 & .589 & .443 & .002 \\
\hline & G.içi & 213.724 & 376 & .568 & & & \\
\hline & Toplam & 214.058 & 377 & & & & \\
\hline \multirow{3}{*}{ 3.Faktör } & G.arası & .112 & 1 & .112 & .286 & .593 & .001 \\
\hline & G.içi & 148.052 & 376 & .394 & & & \\
\hline & Toplam & 148.164 & 377 & & & & \\
\hline \multirow{3}{*}{ 4.Faktör } & G.arası & 1.881 & 1 & 1.881 & 3.406 & .066 & .009 \\
\hline & G.içi & 207.575 & 376 & .552 & & & \\
\hline & Toplam & 209.456 & 377 & & & & \\
\hline \multirow{3}{*}{ 5.Faktör } & G.arası & .100 & 1 & .100 & .154 & .695 & .000 \\
\hline & G.içi & 242.650 & 376 & .645 & & & \\
\hline & Toplam & 242.749 & 377 & & & & \\
\hline \multirow{3}{*}{ TYTÖ } & G.arası & .008 & 1 & .008 & .033 & .857 & .000 \\
\hline & G.içi & 96.835 & 376 & .258 & & & \\
\hline & Toplam & 96.843 & 377 & & & & \\
\hline
\end{tabular}

${ }^{*} \mathrm{a}=.008$

Öğretmenlerin TYT’leri yaşlarına veya hizmet sürelerine göre farklılık göstermekte midir?

Öğretmenlerin yaşlarına göre TYTÖ ortalamaları Tablo 5'teki gibidir.

Tablo 5

Öğretmenlerin Yaşlarına Göre TYTÖ Puanları

\begin{tabular}{|c|c|c|c|c|c|c|c|c|c|c|c|c|c|}
\hline \multirow{2}{*}{ Yaş } & \multicolumn{3}{|c|}{ 1.Faktör } & \multicolumn{2}{|c|}{ 2.Faktör } & \multicolumn{2}{|c|}{ 3.Faktör } & \multicolumn{2}{|c|}{ 4.Faktör } & \multicolumn{2}{|c|}{ 5.Faktör } & \multicolumn{2}{|c|}{ TYTÖ } \\
\hline & $\mathbf{N}$ & $\overline{\mathbf{X}}$ & SS & $\overline{\mathbf{X}}$ & SS & $\overline{\mathbf{X}}$ & SS & $\overline{\mathbf{X}}$ & SS & $\overline{\mathbf{X}}$ & SS & $\overline{\mathbf{X}}$ & SS \\
\hline $21-25$ & 7 & 4.57 & 0.57 & 4.04 & 0.93 & 3.79 & 0.59 & 3.89 & 1.13 & 4.43 & 0.61 & 4.14 & 0.68 \\
\hline $26-3$ & 42 & 4.40 & 0.6 & 4.18 & 0.53 & 3.98 & 0.62 & 3.98 & 0.73 & 4.07 & 0.89 & 4.14 & 0.42 \\
\hline $31-3$ & 57 & 4.28 & 0.73 & 3.84 & 0.91 & 3.79 & 0.65 & 3.95 & 0.82 & 3.89 & 0.97 & 3.97 & 0.60 \\
\hline $36-40$ & 126 & 4.08 & 0.80 & 3.78 & 0.72 & 3.92 & 0.56 & 4.00 & 0.62 & 4.10 & 0.68 & 3.97 & 0.45 \\
\hline $41+$ & 146 & 3.96 & 0.75 & 3.73 & 0.74 & 3.73 & 0.66 & 3.81 & 0.79 & 3.91 & 0.80 & 3.83 & 0.50 \\
\hline
\end{tabular}

MANOVA'ya göre öğretmenlerin TYT'lerinin yaşlarına göre anlamlı farklılık gösterdiği anlaşılmıştır (Pillai's Trace V=.106, F(20,1488)= 2.025, p<.01). Tablo 6'daki ANOVA değerleri dikkate alındığında 26-30 yaş grubundaki öğretmenlerin TYT'lerinin birinci, ikinci faktörlerde ve TYTÖ'nün genelinde 41+ yaş grubundaki öğretmenlerden anlamlı düzeyde yüksek olduğu anlaşılmaktadır. Ayrıca ikinci faktörde 26-30 yaş grubundaki öğretmenlerin TYT'lerinin 36-40 yaş grubundaki öğretmenlerden de yüksek olduğu görülmüştür. 
Tablo 6

Öğretmenlerin Yaşlarına Göre ANOVA Sonuçları

\begin{tabular}{|c|c|c|c|c|c|c|c|c|}
\hline Varyans & & $\begin{array}{l}\text { Kareler } \\
\text { Toplamı }\end{array}$ & sd & $\begin{array}{c}\text { Kareler } \\
\text { Ortalamas1 }\end{array}$ & $\mathbf{F}$ & $\mathrm{p}$ & $\begin{array}{c}\text { Kismi } \\
\eta^{2}\end{array}$ & $\begin{array}{c}\text { Hochberg } \\
\text { GT2 }\end{array}$ \\
\hline \multirow{3}{*}{ 1.Faktör } & G.arası & 10.122 & 4 & 2.531 & 4.474 & .002 & .046 & \multirow{3}{*}{$\begin{array}{c}26-30> \\
41+\end{array}$} \\
\hline & G.içi & 210.991 & 373 & .566 & & & & \\
\hline & Toplam & 221.113 & 377 & & & & & \\
\hline \multirow{3}{*}{ 2.Faktör } & G.arası & 7.143 & 4 & 1.786 & 3.219 & .013 & .033 & \multirow{3}{*}{$\begin{array}{c}26-30>36- \\
40,26- \\
30>41+\end{array}$} \\
\hline & G.içi & 206.915 & 373 & .555 & & & & \\
\hline & Toplam & 214.058 & 377 & & & & & \\
\hline \multirow{3}{*}{ 3.Faktör } & G.arası & 3.328 & 4 & .832 & \multirow[t]{3}{*}{2.143} & .075 & \multirow[t]{3}{*}{.022} & \\
\hline & G.içi & 144.836 & 373 & .388 & & & & \\
\hline & Toplam & 148.164 & 377 & & & & & \\
\hline \multirow{3}{*}{ 4.Faktör } & G.aras1 & 2.717 & 4 & .679 & \multirow[t]{3}{*}{1.226} & .299 & \multirow[t]{3}{*}{.013} & \\
\hline & G.içi & 206.738 & 373 & .554 & & & & \\
\hline & Toplam & 209.456 & 377 & & & & & \\
\hline \multirow{3}{*}{ 5.Faktör } & G.aras1 & 4.720 & 4 & 1.180 & \multirow[t]{3}{*}{1.849} & .119 & \multirow[t]{3}{*}{.019} & \\
\hline & G.içi & 238.029 & 373 & .638 & & & & \\
\hline & Toplam & 242.749 & 377 & & & & & \\
\hline \multirow{3}{*}{ TYTÖ } & G.aras1 & 4.001 & 4 & 1.000 & \multirow[t]{3}{*}{4.019} & .003 & \multirow[t]{3}{*}{.041} & \multirow{3}{*}{$26-30>41+$} \\
\hline & G.içi & 92.842 & 373 & .249 & & & & \\
\hline & Toplam & 96.843 & 377 & & & & & \\
\hline
\end{tabular}

Öğretmenlerin hizmet sürelerine göre TYTÖ ortalamaları Tablo 7'deki gibidir.

Tablo 7

Öğretmenlerin Hizmet Sürelerine Göre TYTÖ Puanlarn

\begin{tabular}{cccccccccccccc}
\hline \multirow{2}{*}{ Hiz. } & \multicolumn{4}{c}{ 1.Faktör } & 2.Faktör & \multicolumn{3}{c}{ 3.Faktör } & \multicolumn{2}{c}{ 4.Faktör } & \multicolumn{2}{c}{ 5.Faktör } & \multicolumn{2}{c}{ TYTÖ } \\
\cline { 2 - 15 } & $\mathbf{N}$ & $\overline{\mathbf{X}}$ & SS & $\overline{\mathbf{X}}$ & SS & $\overline{\mathbf{X}}$ & SS & $\overline{\mathbf{X}}$ & SS & $\overline{\mathbf{X}}$ & SS & $\overline{\mathbf{X}}$ & SS \\
\hline $1-5$ & 54 & 4.36 & 0.62 & 4.03 & 0.70 & 3.90 & 0.56 & 3.97 & 0.79 & 4.11 & 0.82 & 4.09 & 0.45 \\
$6-10$ & 47 & 4.23 & 0.85 & 3.86 & 0.79 & 3.88 & 0.61 & 3.94 & 0.75 & 4.01 & 0.85 & 3.99 & 0.57 \\
$11-15$ & 82 & 4.15 & 0.78 & 3.83 & 0.76 & 3.86 & 0.60 & 3.91 & 0.71 & 3.99 & 0.87 & 3.95 & 0.50 \\
$16-20$ & 112 & 4.00 & 0.79 & 3.75 & 0.74 & 3.80 & 0.63 & 3.96 & 0.72 & 4.00 & 0.69 & 3.90 & 0.50 \\
$21+$ & 83 & 3.99 & 0.71 & 3.74 & 0.77 & 3.77 & 0.71 & 3.80 & 0.79 & 3.92 & 0.85 & 3.84 & 0.51 \\
\hline
\end{tabular}

MANOVA sonucunda öğretmenlerinin TYT'lerinin hizmet sürelerine göre anlamlı farklılık göstermediği anlaşılmıştır (Pillai's Trace V=.049, F(20,1488)= .927, p>.05). Benzer şekilde ANOVA'lar sonucunda da (Tablo 8) öğretmenlerin TYT'lerinde hizmet sürelerine göre anlamlı bir farklılık olmadığı anlaşılmıştır $(a>.008)$. 
Tablo 8

Öğretmenlerin Hizmet Sürelerine Göre ANOVA Sonuçları

\begin{tabular}{|c|c|c|c|c|c|c|c|c|}
\hline Varyans & & $\begin{array}{c}\text { Kareler } \\
\text { Toplamı }\end{array}$ & sd & $\begin{array}{c}\text { Kareler } \\
\text { Ortalaması }\end{array}$ & $\mathbf{F}$ & $\mathrm{p}^{*}$ & $\begin{array}{c}\text { Kismi } \\
\eta^{2}\end{array}$ & $\begin{array}{c}\text { Hochberg } \\
\text { GT2 }\end{array}$ \\
\hline \multirow{3}{*}{ 1.Faktör } & G.aras1 & 6.675 & 4 & 1.669 & 2.903 & .022 & .30 & \\
\hline & G.içi & 214.438 & 373 & .575 & & & & \\
\hline & Toplam & 221.113 & 377 & & & & & \\
\hline \multirow{3}{*}{ 2.Faktör } & G.arası & 3.512 & 4 & .878 & 1.556 & .186 & .016 & \\
\hline & G.içi & 210.546 & 373 & .564 & & & & \\
\hline & Toplam & 214.058 & 377 & & & & & \\
\hline \multirow{3}{*}{ 3.Faktör } & G.arası & .859 & 4 & .215 & .543 & .704 & .006 & \\
\hline & G.içi & 147.305 & 373 & .395 & & & & \\
\hline & Toplam & 148.164 & 377 & & & & & \\
\hline \multirow{3}{*}{ 4.Faktör } & G.aras1 & 1.603 & 4 & .401 & .719 & .579 & .008 & \\
\hline & G.içi & 207.853 & 373 & .557 & & & & \\
\hline & Toplam & 209.456 & 377 & & & & & \\
\hline \multirow{3}{*}{ 5.Faktör } & G.arası & 1.195 & 4 & .299 & .461 & .764 & .005 & \\
\hline & G.içi & 241.555 & 373 & .648 & & & & \\
\hline & Toplam & 242.749 & 377 & & & & & \\
\hline \multirow{3}{*}{ TYTÖ } & G.aras1 & 2.250 & 4 & .563 & 2.218 & .067 & .023 & \\
\hline & G.içi & 94.593 & 373 & .254 & & & & \\
\hline & Toplam & 96.843 & 377 & & & & & \\
\hline
\end{tabular}

\section{Öğretmenlerin TYT’leri branşlarına veya çalıştıkları okul türlerine göre farklılık göstermekte midir?}

Öğretmenlerin branşlarına göre TYTÖ puanları Tablo 9'daki gibidir.

Tablo 9

Öğretmenlerin Branşlarına Göre TYTÖ Puanları

\begin{tabular}{|c|c|c|c|c|c|c|c|c|c|c|c|c|c|}
\hline \multirow{2}{*}{$\begin{array}{c}\text { Bran } \\
\mathrm{s}^{*}\end{array}$} & & \multicolumn{2}{|c|}{ 1.Faktör } & \multicolumn{2}{|c|}{ 2.Faktör } & \multicolumn{2}{|c|}{ 3.Faktör } & \multicolumn{2}{|c|}{ 4.Faktör } & \multicolumn{2}{|c|}{ 5.Faktör } & \multicolumn{2}{|c|}{ TYTÖ } \\
\hline & $\mathbf{N}$ & $\overline{\mathbf{X}}$ & SS & $\overline{\mathbf{X}}$ & SS & $\overline{\mathbf{X}}$ & SS & $\overline{\mathbf{X}}$ & SS & $\overline{\mathbf{X}}$ & SS & $\overline{\mathbf{X}}$ & SS \\
\hline 1 & 69 & 3.94 & 0.74 & 3.53 & 0.74 & 3.66 & 0.64 & 3.78 & 0.85 & 3.91 & 0.84 & 3.76 & 0.54 \\
\hline 2 & 57 & 3.96 & 0.78 & 3.76 & 0.75 & 3.83 & 0.70 & 3.84 & 0.68 & 3.91 & 0.77 & 3.86 & 0.50 \\
\hline 3 & 52 & 4.29 & 0.75 & 3.75 & 0.71 & 3.87 & 0.62 & 3.97 & 0.71 & 4.03 & 0.84 & 3.99 & 0.49 \\
\hline 4 & 50 & 4.08 & 0.72 & 3.73 & 0.79 & 3.85 & 0.59 & 4.00 & 0.79 & 3.96 & 0.70 & 3.93 & 0.48 \\
\hline 5 & 47 & 4.33 & 0.77 & 4.23 & 0.62 & 3.86 & 0.59 & 3.91 & 0.59 & 4.12 & 0.69 & 4.10 & 0.43 \\
\hline 6 & 40 & 3.95 & 0.73 & 3.69 & 0.85 & 3.80 & 0.65 & 3.93 & 0.69 & 4.00 & 0.93 & 3.86 & 0.52 \\
\hline 7 & 32 & 3.86 & 0.80 & 4.03 & 0.59 & 3.84 & 0.53 & 3.74 & 0.75 & 4.08 & 0.84 & 3.89 & 0.47 \\
\hline 8 & 31 & 4.60 & 0.57 & 4.14 & 0.64 & 4.12 & 0.59 & 4.28 & 0.78 & 4.10 & 0.87 & 4.28 & 0.42 \\
\hline
\end{tabular}

*1:Fen, 2:Matematik, 3:Sosyal Meslek, 4:Türk Dili ve Ed.,5:Yabanc1 Dil, 6:Sosyal, 7:Diğger, 8:Teknik Meslek

MANOVA'ya göre öğretmenlerin TYT'lerinin branşlarına göre anlamlı farklılık gösterdiği anlaşılmıştır (Pillai's Trace V=.203, F(35,1850)=2.235, p<.05). Tablo 10'daki istatistiklere göre birinci faktörde ve TYTÖ'nün genelinde Teknik Meslek branşındaki öğretmenlerin TYT'lerinin özellikle Fen, Matematik, Sosyal ve Diğer kodlu branşlardaki öğretmenlerden anlamlı düzeyde daha yüksek olduğu anlaşılmıştır $(\mathrm{p}<.05)$. Ayrıca ikinci faktörde ise ağırlıklı olarak Yabancı Dil 
branşlarındaki öğretmenlerin TYT'lerinin Fen, Matematik, Sosyal, Sosyal Meslek, Türk Dili ve Edebiyatı branşlarındaki öğretmenlerden anlamlı düzeyde yüksek olduğu görülmüştür $(\mathrm{p}<.05)$.

Tablo 10

Öğretmenlerin Branşlarına Göre ANOVA Sonuçlan

\begin{tabular}{|c|c|c|c|c|c|c|c|c|}
\hline Varyans & & $\begin{array}{l}\text { Kareler } \\
\text { Toplamı }\end{array}$ & sd & $\begin{array}{c}\text { Kareler } \\
\text { Ortalaması }\end{array}$ & $\mathbf{F}$ & $\mathrm{p}$ & $\begin{array}{c}\text { K1smi } \\
\eta^{2}\end{array}$ & $\begin{array}{c}\text { Hochberg } \\
\text { GT2 }\end{array}$ \\
\hline \multirow{3}{*}{ 1.Faktör } & G.aras1 & 17.659 & 7 & 2.523 & 4.588 & .000 & .080 & \multirow{3}{*}{$\begin{array}{l}8>1,8>2 \\
8>6,8>7\end{array}$} \\
\hline & G.içi & 203.454 & 370 & .550 & & & & \\
\hline & Toplam & 221.113 & 377 & & & & & \\
\hline \multirow{3}{*}{ 2.Faktör } & G.aras1 & 19.968 & 7 & 2.853 & 5.438 & .000 & .093 & \multirow{3}{*}{$\begin{array}{c}5>1,5>2, \\
5>3,5>4 \\
5>6,7>1 \\
8>1\end{array}$} \\
\hline & G.içi & 194.090 & 370 & .525 & & & & \\
\hline & Toplam & 214.058 & 377 & & & & & \\
\hline \multirow{3}{*}{ 3.Faktör } & G.aras1 & 4.787 & 7 & .684 & 1.765 & .093 & .032 & \\
\hline & G.içi & 143.377 & 370 & .388 & & & & \\
\hline & Toplam & 148.164 & 377 & & & & & \\
\hline \multirow{3}{*}{ 4.Faktör } & G.aras1 & 7.322 & 7 & 1.046 & 1.915 & .066 & .035 & \\
\hline & G.içi & 202.134 & 370 & .546 & & & & \\
\hline & Toplam & 209.456 & 377 & & & & & \\
\hline \multirow{3}{*}{ 5.Faktör } & G.aras1 & 2.212 & 7 & .316 & .486 & .845 & .009 & \\
\hline & G.içi & 240.537 & 370 & .650 & & & & \\
\hline & Toplam & 242.749 & 377 & & & & & \\
\hline \multirow{3}{*}{ TYTÖ } & G.aras1 & 7.915 & 7 & 1.131 & 4.705 & .000 & .082 & $5>1,8>1$ \\
\hline & G.içi & 88.928 & 370 & .240 & & & & $8>2,8>4$, \\
\hline & Toplam & 96.843 & 377 & & & & & $8>6,8>7$ \\
\hline
\end{tabular}

Çalışmada öğretmenlerin TYT'leri çalıştıkları okul türlerine göre analiz edilirken benzer türdeki okullarda çalışan katılımcıların verileri aynı grupta ele alınmıştır (Tablo 11) . Bu doğrultuda Anadolu İmam Hatip Lisesi (69 kişi), Anadolu Ticaret Meslekli ve Teknik Anadolu Lisesinde çalışan (10 kişi) öğretmenler "Sosyal Meslek Lisesi" grubunda; Anadolu Teknik ve Endüstri Meslek Liselerinde çalışan (99 kişi) öğretmenler ise “Teknik Meslek Lisesi” grubunda değerlendirmeye alınmıştır.

Tablo 11

Öğretmenlerin Görev Yaptıklan Okul Türlerine Göre TYTÖ Puanları

\begin{tabular}{cccccccccccccc}
\hline Oku & \multicolumn{4}{c}{ 1.Faktör } & \multicolumn{2}{c}{ 2.Faktör } & \multicolumn{3}{c}{ 3.Faktör } & \multicolumn{3}{c}{ 4.Faktör } & \multicolumn{2}{c}{ 5.Faktör } & \multicolumn{2}{c}{ TYTÖ } \\
\cline { 2 - 13 } $\mathbf{1}^{*}$ & $\mathbf{N}$ & $\overline{\mathbf{X}}$ & SS & $\overline{\mathbf{X}}$ & SS & $\overline{\mathbf{X}}$ & SS & $\overline{\mathbf{X}}$ & SS & $\overline{\mathbf{X}}$ & SS & $\overline{\mathbf{X}}$ & SS \\
\hline 1 & 200 & 4,08 & 0,74 & 3,79 & 0,77 & 3,75 & 0,64 & 3,80 & 0,81 & 3,91 & 0,85 & 3,87 & 0,53 \\
2 & 99 & 4,23 & 0,77 & 3,93 & 0,70 & 3,95 & 0,55 & 4,04 & 0,72 & 4,03 & 0,84 & 4,05 & 0,49 \\
3 & 79 & 4,02 & 0,81 & 3,76 & 0,78 & 3,89 & 0,66 & 4,04 & 0,56 & 4,18 & 0,57 & 3,96 & 0,46 \\
\hline
\end{tabular}

*1:Anadolu ve Fen L., 2:Teknik Meslek L., 3:Sosyal Meslek L.

MANOVA'dan elde edilen Pillai's Trace V=.053, $F(10,744)=2,011$ değerlerine göre öğretmenlerin TYT'leri görev yaptıkları okul türüne göre farklılık göstermektedir ( $<$.05). ANOVA sonucunda (Tablo 12) Anadolu ve Fen Liselerinde görev yapan öğretmenlerin TYT'lerinin dördüncü ve beşinci faktörlerde Sosyal Meslek Liselerinde görev yapan öğretmenlerden; üçüncü, dördüncü faktörlerde ve 
TYTÖ’nnün genelinde Teknik Meslek Liselerinde görev yapan öğretmenlerden daha düşük olduğu anlaşılmıştır ( $p<.05)$.

Tablo 12

Öğretmenlerin Görev Yaptıkları Okul Türlerine Göre ANOVA Sonuçları

\begin{tabular}{|c|c|c|c|c|c|c|c|c|}
\hline Varyans & & $\begin{array}{c}\text { Kareler } \\
\text { Toplamı }\end{array}$ & sd & $\begin{array}{c}\text { Kareler } \\
\text { Ortalamasi }\end{array}$ & F & p & $\begin{array}{c}\text { K1smi } \\
\eta^{2}\end{array}$ & $\begin{array}{c}\text { Hochberg } \\
\text { GT2 }\end{array}$ \\
\hline \multirow{3}{*}{ 1.Faktör } & G.aras1 & 2.311 & 2 & 1.155 & 1.980 & .139 & .010 & \\
\hline & G.içi & 218.802 & 375 & .583 & & & & \\
\hline & Toplam & 221.113 & 377 & & & & & \\
\hline \multirow{3}{*}{ 2.Faktör } & G.aras1 & 1.698 & 2 & .849 & 1.499 & .225 & .008 & \\
\hline & G.içi & 212.360 & 375 & .566 & & & & \\
\hline & Toplam & 214.058 & 377 & & & & & \\
\hline \multirow{3}{*}{ 3.Faktör } & G.aras1 & 2.843 & 2 & 1.422 & 3.668 & .026 & .019 & \multirow{3}{*}{$2>1$} \\
\hline & G.içi & 145.321 & 375 & .388 & & & & \\
\hline & Toplam & 148.164 & 377 & & & & & \\
\hline \multirow{3}{*}{ 4.Faktör } & G.aras1 & 5.286 & 2 & 2.643 & 4.854 & .008 & .025 & \multirow{3}{*}{$2>1,3>1$} \\
\hline & G.içi & 204.170 & 375 & .544 & & & & \\
\hline & Toplam & 209.456 & 377 & & & & & \\
\hline \multirow{3}{*}{ 5.Faktör } & G.aras1 & 4.372 & 2 & 2.186 & 3.439 & .033 & .018 & \multirow{3}{*}{$3>1$} \\
\hline & G.içi & 238.378 & 375 & .636 & & & & \\
\hline & Toplam & 242.749 & 377 & & & & & \\
\hline \multirow{3}{*}{ TYTÖ } & G.arası & 2.052 & 2 & 1.026 & 4.059 & .018 & .021 & \multirow{3}{*}{$2>1$} \\
\hline & G.içi & 94.791 & 375 & .253 & & & & \\
\hline & Toplam & 96.843 & 377 & & & & & \\
\hline
\end{tabular}

Öğretmenlerin TYT'leri mezun oldukları fakülte türüne veya eğitim düzeylerine göre farklılık göstermekte midir?

Araştırmada öğretmenlerin TYT'leri mezun oldukları fakülte türlerine göre üç grup halinde incelenmiştir (Tablo 13). "Eğitim Fakültesi" bünyesine kültür dersleri öğretmenlerinin (165 kişi) yanı sıra teknik eğitim (26 kişi) vb. fakültelerden mezun olmuş öğretmenler de dahil edilmiştir. Öte yandan İlahiyat Fakültesi (30 kişi), sağlık yüksekokulu (5 kişi) ya da mühendislik fakültesi (1 kişi) gibi farklı fakültelerden mezun olan öğretmenler ise "Diğer" kategorisinde değerlendirmeye alınmıştır.

Tablo 13

Öğretmenlerin Mezun Oldukları Fakülte Türlerine Göre TYTÖ Puanları

\begin{tabular}{|c|c|c|c|c|c|c|c|c|c|c|c|c|c|}
\hline \multirow{2}{*}{$\begin{array}{c}\text { Fak. } \\
* \\
\end{array}$} & \multicolumn{3}{|c|}{ 1.Faktör } & \multicolumn{2}{|c|}{ 2.Faktör } & \multicolumn{2}{|c|}{ 3.Faktör } & \multicolumn{2}{|c|}{ 4.Faktör } & \multicolumn{2}{|c|}{ 5.Faktör } & \multicolumn{2}{|c|}{ TYTÖ } \\
\hline & $\mathbf{N}$ & $\overline{\mathbf{X}}$ & SS & $\overline{\mathbf{X}}$ & SS & $\overline{\mathbf{X}}$ & SS & $\overline{\mathbf{X}}$ & SS & $\overline{\mathbf{X}}$ & SS & $\overline{\mathbf{X}}$ & SS \\
\hline 1 & 200 & 4.19 & 0.75 & 3.94 & 0.71 & 3.84 & 0.56 & 3.96 & 0.73 & 4.02 & 0.77 & 4.00 & 0.48 \\
\hline 2 & 138 & 3.96 & 0.77 & 3.68 & 0.82 & 3.82 & 0.70 & 3.82 & 0.81 & 3.94 & 0.88 & 3.84 & 0.54 \\
\hline 3 & 40 & 4.24 & 0.77 & 3.68 & 0.65 & 3.84 & 0.66 & 3.99 & 0.50 & 4.09 & 0.68 & 3.97 & 0.47 \\
\hline
\end{tabular}

*1:Eğitim Fak.,2:Fen Edebiyat, 3:Diğer

MANOVA'ya göre öğretmenlerin TYT'leri mezun oldukları fakülte türlerine göre farklıl1k göstermektedir (Pillai's Trace V=.058, F(10,744)=2,235, p<.05). Tablo 14'teki istatistikler dikkate alındığında Eğitim Fakültesi mezunu öğretmenlerin TYT'lerinin birinci ve ikinci faktörlerde ayrıca ölçek genelinde Fen Edebiyat Fakültesi mezunu öğretmenlerden anlamlı düzeyde yüksek olduğu anlaşılmıştır. 
Tablo 14

Öğretmenlerin Mezun Oldukları Fakülte Türlerine Göre ANOVA Sonuçları

\begin{tabular}{|c|c|c|c|c|c|c|c|c|}
\hline Varyans & & $\begin{array}{l}\text { Kareler } \\
\text { Toplamı }\end{array}$ & sd & $\begin{array}{c}\text { Kareler } \\
\text { Ortalamasi }\end{array}$ & F & p & $\begin{array}{c}\text { Kismi } \\
\eta^{2}\end{array}$ & $\begin{array}{c}\text { Hochberg } \\
\text { GT2 }\end{array}$ \\
\hline \multirow{3}{*}{ 1.Faktör } & G.aras1 & 4.818 & 2 & 2.409 & 4.177 & .016 & .022 & \multirow{3}{*}{$1>2$} \\
\hline & G.ici & 216.295 & 375 & .577 & & & & \\
\hline & Toplam & 221.113 & 377 & & & & & \\
\hline \multirow{3}{*}{ 2.Faktör } & G.aras1 & 6.440 & 2 & 3.220 & 5.816 & .003 & .030 & \multirow{3}{*}{$1>2$} \\
\hline & G.içi & 207.618 & 375 & .554 & & & & \\
\hline & Toplam & 214.058 & 377 & & & & & \\
\hline \multirow{3}{*}{ 3.Faktör } & G.aras1 & .042 & 2 & .021 & .053 & .948 & .000 & \\
\hline & G.içi & 148.122 & 375 & .395 & & & & \\
\hline & Toplam & 148.164 & 377 & & & & & \\
\hline \multirow{3}{*}{ 4.Faktör } & G.aras1 & 1.857 & 2 & .929 & 1.677 & .188 & .009 & \\
\hline & G.içi & 207.598 & 375 & .554 & & & & \\
\hline & Toplam & 209.456 & 377 & & & & & \\
\hline \multirow{3}{*}{ 5.Faktör } & G.aras1 & .849 & 2 & .425 & .658 & .518 & .003 & \\
\hline & G.içi & 241.900 & 375 & .645 & & & & \\
\hline & Toplam & 242.749 & 377 & & & & & \\
\hline \multirow{3}{*}{ TYTÖ } & G.aras1 & 2.020 & 2 & 1.010 & 3.994 & .019 & .021 & \multirow{3}{*}{$1>2$} \\
\hline & G.içi & 94.824 & 375 & .253 & & & & \\
\hline & Toplam & 96.843 & 377 & & & & & \\
\hline
\end{tabular}

Araştırmada öğretmenlerin TYT'leri eğitim düzeylerine göre incelenirken tezsiz yüksek lisans (49 kişi), tezli yüksek lisans (31 kişi) ve doktora (2 kişi) derecesine sahip öğretmenlerin tamamı "Lisansüstü" kategorisinde değerlendirmeye alınmıştır (Tablo 15).

Tablo 15

Öğretmenlerin Eğitim Düzeylerine Göre TYTÖ Puanları

\begin{tabular}{|c|c|c|c|c|c|c|c|c|c|c|c|c|c|}
\hline \multirow{2}{*}{ Ĕgt. ${ }^{*}$} & \multicolumn{3}{|c|}{ 1.Faktör } & \multicolumn{2}{|c|}{ 2.Faktör } & \multicolumn{2}{|c|}{ 3.Faktör } & \multicolumn{2}{|c|}{ 4.Faktör } & \multicolumn{2}{|c|}{ 5.Faktör } & \multicolumn{2}{|c|}{ TYTÖ } \\
\hline & $\mathbf{N}$ & $\overline{\mathbf{X}}$ & SS & $\overline{\mathbf{X}}$ & SS & $\overline{\mathbf{X}}$ & SS & $\overline{\mathbf{X}}$ & SS & $\overline{\mathbf{X}}$ & SS & $\overline{\mathbf{X}}$ & SS \\
\hline 1 & 296 & 4.11 & 0.78 & 3.83 & 0.75 & 3.83 & 0.63 & 3.93 & 0.74 & 4.02 & 0.78 & 3.94 & 0.50 \\
\hline 2 & 82 & 4.10 & 0.72 & 3.76 & 0.77 & 3.84 & 0.61 & 3.86 & 0.78 & 3.94 & 0.87 & 3.91 & 0.53 \\
\hline
\end{tabular}

*1:Lisans. 2:Lisansüstü

MANOVA'ya göre öğretmenlerin TYT'lerinin eğitim düzeylerine göre anlamlı farklılık göstermediği anlaşılmıştır (Pillai's Trace $V=.005, F(5,372)=.352, \mathrm{p}>.05$ ). Benzer şekilde gerçekleştirilen ANOVA'lar neticesinde de (Tablo 16) anlamlı bir farklılığa rastlanmamıştır ( $\mathrm{p}>.008)$. 
Tablo 16

Öğretmenlerin Ĕ̆itim Düzeylerine Göre ANOVA Sonuçları

\begin{tabular}{|c|c|c|c|c|c|c|c|}
\hline \multicolumn{2}{|c|}{ Varyans } & $\begin{array}{c}\text { Kareler } \\
\text { Toplamı }\end{array}$ & sd & $\begin{array}{c}\text { Kareler } \\
\text { Ortalamas1 }\end{array}$ & $\mathbf{F}$ & $\mathrm{p}^{*}$ & $\begin{array}{c}\text { K1sm } \\
\eta^{2}\end{array}$ \\
\hline \multirow{3}{*}{ 1.Faktör } & G.aras1 & .012 & 1 & .012 & .021 & .884 & .000 \\
\hline & G.içi & 221.100 & 376 & .588 & & & \\
\hline & Toplam & 221.113 & 377 & & & & \\
\hline \multirow{3}{*}{ 2.Faktör } & G.aras1 & .364 & 1 & .364 & .641 & .424 & .002 \\
\hline & G.icii & 213.694 & 376 & .568 & & & \\
\hline & Toplam & 214.058 & 377 & & & & \\
\hline \multirow{3}{*}{ 3.Faktör } & G.arası & .006 & 1 & .006 & .016 & .900 & .000 \\
\hline & G.icii & 148.158 & 376 & .394 & & & \\
\hline & Toplam & 148.164 & 377 & & & & \\
\hline \multirow{3}{*}{ 4.Faktör } & G.arası & .275 & 1 & .275 & .494 & .483 & .001 \\
\hline & G.içi & 209.181 & 376 & .556 & & & \\
\hline & Toplam & 209.456 & 377 & & & & \\
\hline \multirow{3}{*}{ 5.Faktör } & G.arası & .373 & 1 & .373 & .578 & .448 & .002 \\
\hline & G.içi & 242.377 & 376 & .645 & & & \\
\hline & Toplam & 242.749 & 377 & & & & \\
\hline \multirow{3}{*}{ TYTÖ } & G.aras1 & .099 & 1 & .099 & .384 & .536 & .001 \\
\hline & G.içi & 96.745 & 376 & .257 & & & \\
\hline & Toplam & 96.843 & 377 & & & & \\
\hline
\end{tabular}

${ }^{*} \alpha=.008$

Öğretmenlerin TYT'leri derslerinde teknoloji kullanımı hakkında eğitim almalarına göre farklılık göstermekte midir?

Öğretmenlerin derslerinde teknoloji kullanımı hakkında eğitim almalarına göre TYTÖ puanları Tablo 17'deki gibidir.

Tablo 17

Öğretmenlerin Derslerinde Teknoloji Kullanımı Hakkında Ĕ̆itim Almalarına Göre TYTÖ Puanları

\begin{tabular}{|c|c|c|c|c|c|c|c|c|c|c|c|c|c|}
\hline \multirow{2}{*}{ Eğt. } & & \multicolumn{2}{|c|}{ 1.Faktör } & \multicolumn{2}{|c|}{ 2.Faktör } & \multicolumn{2}{|c|}{ 3.Faktör } & \multicolumn{2}{|c|}{ 4.Faktör } & \multicolumn{2}{|c|}{ 5.Faktör } & \multicolumn{2}{|c|}{ TYTÖ } \\
\hline & $\mathbf{N}$ & $\overline{\mathbf{X}}$ & SS & $\overline{\mathbf{X}}$ & SS & $\overline{\mathbf{X}}$ & SS & $\overline{\mathbf{X}}$ & SS & $\overline{\overline{\mathbf{x}}}$ & SS & $\overline{\mathbf{X}}$ & SS \\
\hline$E$ & 258 & 4.17 & 0.72 & 3.82 & 0.76 & 3.84 & 0.65 & 3.94 & 0.78 & 4.01 & 0.81 & 3.96 & 0.50 \\
\hline $\mathrm{H}$ & 120 & 3.99 & 0.85 & 3.81 & 0.75 & 3.82 & 0.59 & 3.85 & 0.66 & 3.98 & 0.78 & 3.88 & 0.52 \\
\hline
\end{tabular}

E: Evet eğitim aldım, H: Hayır eğitim almadım

MANOVA sonucunda öğretmenlerin TYT'lerinin derslerinde teknoloji kullanımı hakkında eğitim almış olmalarına göre anlamlı farklılık göstermediği anlaşılmıştır (Pillai's Trace V=.014, $\mathrm{F}(5,372)=1.040, \mathrm{p}>.05$ ). Benzer şekilde izleme testleri neticesinde de (Tablo 18) farklılı̆̆a rastlanmamıştır ( $p>.008)$. 
Tablo 18

Öğretmenlerin Derslerinde Teknoloji Kullanımı Hakkında Eğitim Almalarına Göre ANOVA

Sonuçları

\begin{tabular}{|c|c|c|c|c|c|c|c|}
\hline \multicolumn{2}{|c|}{ Varyans } & Kareler Toplamı & sd & Kareler Ortalaması & $\mathbf{F}$ & $\mathrm{p}^{*}$ & Kismi $\eta^{2}$ \\
\hline \multirow{3}{*}{ 1.Faktör } & G.aras1 & 2.608 & 1 & 2.608 & 4.488 & .035 & .012 \\
\hline & G.içi & 218.505 & 376 & .581 & & & \\
\hline & Toplam & 221.113 & 377 & & & & \\
\hline \multirow{3}{*}{ 2.Faktör } & G.aras1 & .025 & 1 & .025 & .044 & .835 & .000 \\
\hline & G.içi & 214.034 & 376 & .569 & & & \\
\hline & Toplam & 214.058 & 377 & & & & \\
\hline \multirow{3}{*}{ 3.Faktör } & G.aras1 & .035 & 1 & .035 & .088 & .767 & .000 \\
\hline & G.içi & 148.129 & 376 & .394 & & & \\
\hline & Toplam & 148.164 & 377 & & & & \\
\hline \multirow{3}{*}{ 4.Faktör } & G.aras1 & .721 & 1 & .721 & 1.298 & .255 & .003 \\
\hline & G.içi & 208.735 & 376 & .555 & & & \\
\hline & Toplam & 209.456 & 377 & & & & \\
\hline \multirow{3}{*}{ 5.Faktör } & G.aras1 & .067 & 1 & .067 & .104 & .748 & .000 \\
\hline & G.içi & 242.682 & 376 & .645 & & & \\
\hline & Toplam & 242.749 & 377 & & & & \\
\hline \multirow{3}{*}{ TYTÖ } & G.aras1 & .495 & 1 & .495 & 1.930 & .166 & .005 \\
\hline & G.içi & 96.349 & 376 & .256 & & & \\
\hline & Toplam & 96.843 & 377 & & & & \\
\hline
\end{tabular}

Öğretmenlerin TYT'leri derslerinde teknolojik araçları kullanma sıklıklarına göre farklılık göstermekte midir?

Öğretmenlerin teknolojiden yararlanma sıklıklarına göre TYTÖ puanları Tablo 19 'daki gibidir.

Tablo 19

Öğretmenlerin Derslerinde Teknolojik Araçlardan Yararlanma Sıklıklarına Göre TYTÖ Puanları

\begin{tabular}{cccccccccccccc}
\hline \multirow{2}{*}{ S1k.* } & \multicolumn{1}{c}{ 1.Faktör } & \multicolumn{2}{c}{ 2.Faktör } & \multicolumn{2}{c}{ 3.Faktör } & \multicolumn{2}{c}{ 4.Faktör } & \multicolumn{2}{c}{ 5.Faktör } & \multicolumn{3}{c}{ TYTÖ } \\
\cline { 2 - 15 } & $\mathbf{N}$ & $\overline{\mathbf{X}}$ & SS & $\overline{\mathbf{X}}$ & SS & $\overline{\mathbf{X}}$ & SS & $\overline{\mathbf{X}}$ & SS & $\overline{\mathbf{X}}$ & SS & $\overline{\mathbf{X}}$ & SS \\
\hline 0 & 39 & 3.82 & 0.87 & 3.63 & 0.77 & 3.71 & 0.55 & 3.72 & 0.69 & 3.81 & 0.67 & 3.73 & 0.54 \\
1 & 29 & 3.86 & 0.60 & 3.57 & 0.82 & 3.69 & 0.51 & 3.72 & 0.76 & 4.10 & 0.70 & 3.76 & 0.48 \\
2 & 37 & 3.93 & 0.90 & 3.84 & 0.59 & 3.84 & 0.59 & 3.89 & 0.58 & 3.97 & 0.72 & 3.89 & 0.43 \\
3 & 87 & 4.04 & 0.78 & 3.80 & 0.78 & 3.76 & 0.64 & 3.95 & 0.72 & 4.00 & 0.83 & 3.91 & 0.52 \\
4 & 186 & 4.28 & 0.70 & 3.90 & 0.75 & 3.91 & 0.66 & 3.97 & 0.79 & 4.03 & 0.84 & 4.03 & 0.50 \\
\hline
\end{tabular}

${ }^{*} 0$ :Kullanımı yok, 1:Belli konularda nadiren, 2:Ayda birkaç kez, 3:Haftada birkaç kez, 4:Hemen hemen her ders

MANOVA sonucunda öğretmenlerin TYT'lerinin derslerinde teknolojik araçları kullanma sıklıklarına göre anlamlı farklılık gösterdiği anlaşılmıştır (Pillai's Trace $\mathrm{V}=.087, \mathrm{~F}(20,1488)=1.656, \mathrm{p}<.05)$. ANOVA'ya göre (Tablo 20) hemen hemen her dersinde teknolojik araçlardan yararlanan öğretmenlerin TYT'lerinin ölçeğin birinci faktöründe $\left(\mathrm{F}(4,377)=5.374, \mathrm{p}<.001, \mathrm{~K}\right.$ 1smi $\left.\mathrm{\eta}^{2}=.054\right)$ ve genelinde derslerinde teknolojiden yararlanmayan öğretmenlerden anlamlı düzeyde yüksek olduğu anlaş1lmıştır $(\mathrm{F}(4,377)=4.270, \mathrm{p}<.05$, Kısmi $\eta 2=.044)$. 
Tablo 20

Öğretmenlerin Derslerinde Teknolojik Araçlardan Yararlanma Sıklıklarına Göre ANOVA Sonuçlan

\begin{tabular}{|c|c|c|c|c|c|c|c|c|}
\hline \multicolumn{2}{|c|}{ Varyans } & $\begin{array}{c}\text { Kareler } \\
\text { Toplamı }\end{array}$ & sd & $\begin{array}{c}\text { Kareler } \\
\text { Ortalamas1 }\end{array}$ & $\mathbf{F}$ & $\mathbf{p}$ & $\begin{array}{c}\text { Kismi } \\
\eta^{2}\end{array}$ & $\begin{array}{c}\text { Hochberg } \\
\text { GT2 }\end{array}$ \\
\hline \multirow{3}{*}{ 1.Faktör } & G.arası & 12.049 & 4 & 3.012 & 5.374 & .000 & .054 & $4>0$ \\
\hline & G.içi & 209.064 & 373 & .560 & & & & \\
\hline & Toplam & 221.113 & 377 & & & & & \\
\hline \multirow{3}{*}{ 2.Faktör } & G.arası & 4.431 & 4 & 1.108 & 1.971 & .098 & .021 & \\
\hline & G.içi & 209.627 & 373 & .562 & & & & \\
\hline & Toplam & 214.058 & 377 & & & & & \\
\hline \multirow{3}{*}{ 3.Faktör } & G.arası & 2.744 & 4 & .686 & 1.760 & .136 & .019 & \\
\hline & G.içi & 145.420 & 373 & .390 & & & & \\
\hline & Toplam & 148.164 & 377 & & & & & \\
\hline \multirow{3}{*}{ 4.Faktör } & G.arası & 3.170 & 4 & .792 & 1.433 & .222 & .015 & \\
\hline & G.içi & 206.286 & 373 & .553 & & & & \\
\hline & Toplam & 209.456 & 377 & & & & & \\
\hline \multirow{3}{*}{ 5.Faktör } & G.arası & 1.913 & 4 & .478 & .741 & .565 & .008 & \\
\hline & G.içi & 240.836 & 373 & .646 & & & & \\
\hline & Toplam & 242.749 & 377 & & & & & \\
\hline \multirow{3}{*}{ TYTÖ } & G.arası & 4.240 & 4 & 1.060 & 4.270 & .002 & .044 & $4>0$ \\
\hline & G.içi & 92.603 & 373 & .248 & & & & \\
\hline & Toplam & 96.843 & 377 & & & & & \\
\hline
\end{tabular}

Öğretmenlerin TYT’leri derslerinde kullandıkları teknolojik araç veya bilgisayar yazılımı çeşitliliğine göre farklılık göstermekte midir?

Araştırmada öğretmenlerin derslerde çeşitli teknolojik araçlardan yararlandıkları (Tablo 21) ve bunların arasından akıllı tahtanın en çok kullanılan araç olduğu anlaşılmıştır (315 kişi \% 83.3). Ayrıca öğretmenlerin çok büyük bir kısmının (201 kişi \%53.17) derslerinde sadece akıllı tahtadan yararlandıkları da anlaşılmıştır. Bu nedenle öğretmenlerin TYT'leri incelenirken kullandıkları araç sayısı dikkate alınmıştır (Tablo 22). Bu bağlamda derslerinde üç ve daha fazla araç kullanan öğretmenlerin verileri "Çoklu Araç Kullanımı" kategorisinde değerlendirmeye alınmıştır.

Tablo 21

Öğretmenlerin Derslerinde Yararlandıkları Teknolojik Araçlar

\begin{tabular}{lc}
\hline Teknolojik araçlar & $\mathbf{f ~ ( \% )}$ \\
\hline Akıllı Tahta & $315(\% 83.3)$ \\
Tablet Bilgisayar & $56(\% 14,8)$ \\
Bilgisayar & $96(\% 25,4)$ \\
Projeksiyon Cihazı & $33(\% 8.7)$ \\
Diğer (Akıllı telefon vb.) & $12(\% 3.2)$ \\
\hline
\end{tabular}

Öğretmenlerin derslerinde kullandıkları teknolojik araç çeşitliliğine göre TYTÖ ortalamaları Tablo 22' deki gibidir. 
Tablo 22

Öğretmenlerin Derslerinde Kullandıkları Teknolojik Araç Çeşitliliğine Göre TYTÖ Puanları

\begin{tabular}{cccccccccccccc}
\hline \multirow{2}{*}{ Araç* $^{*}$} & \multicolumn{1}{c}{ 1.Faktör } & \multicolumn{3}{c}{ 2.Faktör } & \multicolumn{3}{c}{ 3.Faktör } & \multicolumn{3}{c}{ 4.Faktör } & \multicolumn{2}{c}{ 5.Faktör } & \multicolumn{2}{c}{ TYTÖ } \\
\hline & $\mathbf{N}$ & $\overline{\mathbf{X}}$ & SS & $\overline{\mathbf{X}}$ & SS & $\overline{\mathbf{X}}$ & SS & $\overline{\mathbf{X}}$ & SS & $\overline{\mathbf{X}}$ & SS & $\overline{\mathbf{X}}$ & SS \\
\hline 0 & 39 & 3.82 & 0.87 & 3.63 & 0.77 & 3.71 & 0.55 & 3.72 & 0.69 & 3.81 & 0.67 & 3.73 & 0.54 \\
1 & 211 & 4.04 & 0.73 & 3.71 & 0.78 & 3.76 & 0.66 & 3.84 & 0.72 & 3.98 & 0.81 & 3.86 & 0.50 \\
2 & 93 & 4.17 & 0.79 & 3.97 & 0.62 & 3.94 & 0.54 & 4.08 & 0.76 & 4.11 & 0.79 & 4.05 & 0.44 \\
3 & 35 & 4.69 & 0.40 & 4.29 & 0.63 & 4.07 & 0.66 & 4.14 & 0.81 & 4.01 & 0.94 & 4.29 & 0.46 \\
\hline${ }^{*}$ 0:Kullanım1 yok, 1:Tek Araç, 2:İki araç, 3:Çoklu araç
\end{tabular}

MANOVA'ya göre öğretmenlerin TYT'lerinin derslerinde kullandıkları teknolojik araç çeşitliliğine göre anlamlı farklılık gösterdiği anlaşılmıştır (Pillai's Trace $\mathrm{V}=.129, \mathrm{~F}(15,1116)=3.350, \mathrm{p}<.001)$. Tablo 23'teki ANOVA istatistikleri dikkate alındığında bu farklılığın TYTÖ'nün genelinde ve beşinci faktör hariç bütün faktörlerinde gözlendiği anlaşılmaktadır. Bu durumu özetlemek için TYTÖ geneline ait veriler ele alınabilir. Genel olarak derslerinde çoklu ve iki araç kullanan öğretmenlerin TYT'lerinin derslerinde tek araç kullanan veya teknolojik araç kullanmayan öğretmenlerden yüksek olduğu anlaşılmaktadır $(F(3,377)=11.732$, $\mathrm{p}<.001$, Kismi $\eta 2=.086$ ).

Tablo 23

Öğretmenlerin Derslerinde Kullandıkları Teknolojik Araç Çeşitliliğine Göre ANOVA Sonuçları

\begin{tabular}{|c|c|c|c|c|c|c|c|c|}
\hline \multicolumn{2}{|c|}{ Varyans } & $\begin{array}{c}\text { Kareler } \\
\text { Toplamı }\end{array}$ & sd & $\begin{array}{c}\text { Kareler } \\
\text { Ortalaması }\end{array}$ & $\mathbf{F}$ & p & $\begin{array}{c}\text { Kismi } \\
\eta^{2}\end{array}$ & $\begin{array}{c}\text { Hochberg } \\
\text { GT2 }\end{array}$ \\
\hline \multirow{3}{*}{ 1.Faktör } & G.arası & 16.465 & 3 & 5.488 & 10.030 & .000 & .074 & $3>0,3>1,3>2$ \\
\hline & G.içi & 204.648 & 374 & .547 & & & & \\
\hline & Toplam & 221.113 & 377 & & & & & \\
\hline \multirow{3}{*}{ 2.Faktör } & G.arası & 13.493 & 3 & 4.498 & 8.387 & .000 & .063 & $2>1,3>0,3>1$ \\
\hline & G.içi & 200.566 & 374 & .536 & & & & \\
\hline & Toplam & 214.058 & 377 & & & & & \\
\hline \multirow{3}{*}{ 3.Faktör } & G.aras1 & 4.760 & 3 & 1.587 & 4.138 & .007 & .032 & $3>1$ \\
\hline & G.içi & 143.404 & 374 & .383 & & & & \\
\hline & Toplam & 148.164 & 377 & & & & & \\
\hline \multirow{3}{*}{ 4.Faktör } & G.arası & 6.927 & 3 & 2.309 & 4.264 & .006 & .033 & $2>1$ \\
\hline & G.içi & 202.529 & 374 & .542 & & & & \\
\hline & Toplam & 209.456 & 377 & & & & & \\
\hline \multirow{3}{*}{ 5.Faktör } & G.arası & 2.582 & 3 & .861 & 1.340 & .261 & .011 & \\
\hline & G.içi & 240.167 & 374 & .642 & & & & \\
\hline & Toplam & 242.749 & 377 & & & & & \\
\hline \multirow{3}{*}{ TYTÖ } & G.arası & 8.330 & 3 & 2.777 & 11.732 & .000 & .086 & $2>0,2>1,3>0$, \\
\hline & G.içi & 88.514 & 374 & .237 & & & & $3>1$ \\
\hline & Toplam & 96.843 & 377 & & & & & \\
\hline
\end{tabular}

Araştırmada öğretmenlerin derslerinde çoğunlukla PDF okuyucu (240 kişi \%63.5), Ms PowerPoint gibi sunum programları (276 kişi \%73) ve MS Word tarzı kelime işlemcisi (143 kişi \%37.8) programları kullandıkları anlaşılmıştır (Tablo 24). 
Tablo 24

Öğretmenlerin Derslerinde Yararlandıkları Bilgisayar Programları

\begin{tabular}{lc}
\hline Bilgisayar Programları & $\mathbf{f ~ ( \% )}$ \\
\hline PDF Okuyucu & $240(\% 63.5)$ \\
Sunum Programları & $276(\% 73.0)$ \\
Kelime İşlemcisi & $143(\% 37.8)$ \\
Multimedya Oynatıcısı & $141(\% 37.3)$ \\
Diğer & $11(\% 2.9)$ \\
\hline
\end{tabular}

Araştırmada öğretmenlerin kullandıkları bilgisayar programı çeşitliliğine göre TYT'leri, kullandıkları program sayısı dikkate alınarak incelenmiştir (Tablo 25). Ayrıca derslerinde üç veya daha fazla bilgisayar programı kullanan öğretmenlerin verileri "Çoklu Program Kullanımı" kategorisinde değerlendirmeye alınmıştır.

Tablo 25

Öğretmenlerin Derslerinde Kullandıkları Bilgisayar Programı Çeşitliliğine Göre TYTÖ Puanları

\begin{tabular}{|c|c|c|c|c|c|c|c|c|c|c|c|c|c|}
\hline \multirow{2}{*}{ Prg." } & \multicolumn{3}{|c|}{ 1.Faktör } & \multicolumn{2}{|c|}{ 2.Faktör } & \multicolumn{2}{|c|}{ 3.Faktör } & \multicolumn{2}{|c|}{ 4.Faktör } & \multicolumn{2}{|c|}{ 5.Faktör } & \multicolumn{2}{|c|}{ TYTÖ } \\
\hline & $\mathbf{N}$ & $\overline{\mathbf{X}}$ & SS & $\overline{\mathbf{X}}$ & SS & $\overline{\mathbf{X}}$ & SS & $\overline{\mathbf{X}}$ & SS & $\overline{\mathrm{X}}$ & SS & $\overline{\mathbf{X}}$ & SS \\
\hline 0 & 39 & 3.82 & 0.87 & 3.63 & 0.77 & 3.71 & 0.55 & 3.72 & 0.69 & 3.81 & 0.67 & 3.73 & 0.54 \\
\hline 1 & 83 & 3.88 & 0.72 & 3.63 & 0.85 & 3.72 & 0.73 & 3.62 & 0.80 & 3.82 & 0.85 & 3.73 & 0.59 \\
\hline 2 & 97 & 4.03 & 0.82 & 3.81 & 0.69 & 3.79 & 0.62 & 3.88 & 0.71 & 3.99 & 0.79 & 3.90 & 0.45 \\
\hline 3 & 159 & 4.35 & 0.66 & 3.97 & 0.70 & 3.94 & 0.57 & 4.13 & 0.69 & 4.14 & 0.79 & 4.12 & 0.41 \\
\hline
\end{tabular}

MANOVA'ya göre öğretmenlerin TYT'lerinin derslerinde kullandıkları bilgisayar programı çeşitliliğine göre anlamlı farklılık gösterdiği anlaşılmıştır (Pillai's Trace $V=.131, \mathrm{~F}(15,1116)=3.401, \mathrm{p}<.001)$. Gerçekleştirilen ANOVA sonucunda (Tablo 26) derslerinde çoklu bilgisayar programı kullanan öğretmenlerin TYT'lerinin ikinci, üçüncü ve beşinci faktörlerde sadece tek program kullanan öğretmenlerden yüksekken; birinci, dördüncü faktörlerde ve TYTÖ'nün genelinde ise diğer gruplardaki bütün öğretmenlerden anlamlı düzeyde yüksek olduğu anlaşılmıştır $(\mathrm{p}<.05)$. 
Tablo 26

Öğretmenlerin Derslerinde Kullandıkları Bilgisayar Programı Çeşittiliğine Göre ANOVA Sonuçlan

\begin{tabular}{|c|c|c|c|c|c|c|c|c|}
\hline \multicolumn{2}{|c|}{ Varyans } & $\begin{array}{c}\text { Kareler } \\
\text { Toplamı }\end{array}$ & sd & $\begin{array}{c}\text { Kareler } \\
\text { Ortalamasi }\end{array}$ & F & $\mathrm{p}$ & $\begin{array}{c}\text { K1smi } \\
\eta^{2}\end{array}$ & $\begin{array}{c}\text { Hochberg } \\
\text { GT2 }\end{array}$ \\
\hline \multirow{3}{*}{ 1.Faktör } & G.aras1 & 17.226 & 3 & 5.742 & 10.533 & .000 & .078 & $3>0,3>1,3>2$ \\
\hline & G.içi & 203.887 & 374 & .545 & & & & \\
\hline & Toplam & 221.113 & 377 & & & & & \\
\hline \multirow{3}{*}{ 2.Faktör } & G.aras1 & 7.965 & 3 & 2.655 & 4.818 & .003 & .037 & $3>1$ \\
\hline & G.içi & 206.094 & 374 & .551 & & & & \\
\hline & Toplam & 214.058 & 377 & & & & & \\
\hline \multirow{3}{*}{ 3.Faktör } & G.aras1 & 3.730 & 3 & 1.243 & 3.219 & .023 & .025 & $3>1$ \\
\hline & G.içi & 144.434 & 374 & .386 & & & & \\
\hline & Toplam & 148.164 & 377 & & & & & \\
\hline \multirow{3}{*}{ 4.Faktör } & G.aras1 & 16.459 & 3 & 5.486 & 10.632 & .000 & .079 & $3>0,3>1,3>2$ \\
\hline & G.içi & 192.997 & 374 & .516 & & & & \\
\hline & Toplam & 209.456 & 377 & & & & & \\
\hline \multirow{3}{*}{ 5.Faktör } & G.aras1 & 7.490 & 3 & 2.497 & 3.969 & .008 & .031 & $3>1$ \\
\hline & G.içi & 235.259 & 374 & .629 & & & & \\
\hline & Toplam & 242.749 & 377 & & & & & \\
\hline \multirow{3}{*}{ TYTÖ } & G.aras1 & 10.313 & 3 & 3.438 & 14.858 & .000 & .106 & $3>0,3>1,3>2$ \\
\hline & G.içi & 86.531 & 374 & .231 & & & & \\
\hline & Toplam & 96.843 & 377 & & & & & \\
\hline
\end{tabular}

Tartışma, Sonuç ve Öneriler

Araştırmaya katılan öğretmenlerin TYTÖ genelinden ve faktörlerinden aldıkları puanlar ele alındığında TYT'lerinin "olumlu” olduğu anlaşılmaktadır. Bu sonuç, katılımcıları öğretmen (Çakır ve Oktay, 2013; Üstün ve Akman, 2015) veya öğretmen adayı olan (Birkollu vd., 2017; Kayalar, 2018; Paşa vd., 2015) birçok çalışmanın bulgularıyla örtüşmektedir. Ayrıca öğretmenlerin TYT'leri cinsiyetleri yönünden incelendiğinde herhangi bir farklılığa rastlanmamıştır. Bu sonuç her ne kadar kadınlar (Bisgin, 2014; Çakır ve Oktay, 2013) ya da erkekler (Birkollu vd., 2017; Şahin ve Namlı, 2019) lehine farklılıkların gözlendiği bazı çalışmaların bulgularıyla çelişse de literatürdeki birçok çalışmanın bulgularıyla uyumludur (Dursun vd., 2017; Fındıkoğlu vd., 2015; Kayalar, 2018; Şimşek ve Yıldırım, 2016). Nitekim Cai, Fan ve Du (2017) gerçekleştirdikleri meta analizi çalışmasında küçük bir etki büyüklüğüyle erkeklerin TYT'lerinin kadınlarınkinden yüksek olduğu, fakat araştırmalardaki bu farkların zamanla azaldığı sonucuna varmışlardır.

Araştırmada öğretmenlerin TYT'leri yaşları ve hizmet süreleri yönünden ele alındığında farklı bir durumla karşılaşılmıştır. Öğretmenlerin TYT'leri yaşları yönünden ele alındığında daha önce Bişgin (2014)'ün de tespit ettiği üzere genç öğretmenlerin tutumlarının daha yüksek olduğu anlaşılmıştır. Bu durum Prensky (2001)'nin dijital doğanlar olarak tarif ettiği grubun dijital göçmenlerin yerini alması olarak düşünülebilir. Öte yandan öğretmenlerin TYT'leri hizmet süreleri yönünden ele alındığında ise beklenenin ve literatürdeki çalışmaların (Çakır ve Oktay, 2013) aksine öğretmenlerin tutumlarında anlamlı bir farklılığa rastlanmamıştır. Her ne kadar TYTÖ'nün genelinde ve bütün faktörlerinde öğretmenlerin hizmet süreleri arttıkça tutum ortalamalarının düştüğü gözlemlense de herhangi bir anlamlı farklılık gözlemlenmemiştir. Bu bağlamda genç öğretmenler lehine anlamlı farklılıklar gözlemlenirken hizmet süreleri yönünden bunun gözlenmemesi öğretmenlerin 
yaşları ile hizmet sürelerinin orantılı olmamasından kaynaklanmış olabilir. Nitekim ilgili betimsel istatistikler incelendiğinde özellikle "36-40" ve " $41+$ " yaşlarında olan öğretmenlerin hizmet sürelerine göre grup dağılımlarının büyük oranda çeşitlilik göstermesi bu çıkarımı destekler niteliktedir.

Araştırmada öğretmenlerin TYT'lerinin daha önceki çalışmalardan farklı olarak (Albayrak-Sarı vd., 2016; Çakır ve Oktay, 2013) branşları yönünden farklılık gösterdiği anlaşılmıştır. Öte yandan bu sonuç öğretmen adaylarının TYT'lerinin bölümlerine göre farklılık gösterdiğinin anlaşıldığı bir çok çalışmanın sonucuyla örtüşmektedir (Birkollu vd., 2017; Findıkoğlu vd., 2015; Kayalar, 2018; Şahin ve Namlı, 2019). Anlamlı farklılıkların gözlendiği birinci faktör ve TYTÖ geneli ele alındığında aralarında bilgisayar ve öğretim teknolojileri öğretmenlerinin de yer aldığı, teknik meslek branşları lehine farklılıklar olduğu görülmüştür. Nitekim öğretmen adaylarının bölümlerine göre TYT'lerinde farklılıkların gözlendiği birçok çalışmada da bilgisayar ve öğretim teknolojileri öğretmenliği adayları lehine benzer sonuçlara varılmıştır (Birkollu vd., 2017; Kayalar, 2018; Şahin ve Namlı, 2019). Bu durum teknik branşlardaki öğretmenlerin uzmanlık alanlarından dolayı diğer öğretmenlerden daha fazla yazılım ve donanım bilgisine sahip olmalarından kaynaklanmış olabilir. Benzer bir duruma teknik branşlardaki öğretmenlerin çokça görev yaptıkları okul türlerinde de rastlanmış olması bu çıkarımı destekler niteliktedir. Nitekim teknik meslek liselerindeki öğretmenlerin üçüncü ve dördüncü faktörlerdeki ayrıca TYTÖ’́nün genelindeki tutumlarının anadolu ve fen liselerinde görev yapan öğretmenlerden daha yüksek olduğu anlaşılmıştır. Öte yandan sosyal meslek liselerinde görev yapan öğretmenlerin dördüncü ve beşinci faktörlerdeki tutumlarının da benzer şekilde anadolu ve fen liselerinde görev yapan öğretmenlerden yüksek olması dikkat çekicidir.

Araştırmada öğretmenlerin TYT’leri eğitim düzeyleri yönünden ele alındığında hemen hemen her faktörde ve ölçek genelinde lisansüstü derecesine sahip öğretmenlerin tutumlarının daha yüksek olduğu anlaşılmıştır. Fakat daha önceki çalışmaların da aksine (Çakır ve Oktay, 2013) bu bağlamda herhangi bir anlamlı farklılığa rastlanmamıştır. Öte yandan öğretmenlerin TYT'leri mezunu oldukları fakülte türleri yönünden incelendiğinde ise küçük etki büyüklükleriyle de olsa Eğitim Fakültesi mezunlarının tutumlarının Fen Edebiyat Fakültesi mezunlarından anlamlı düzeyde yüksek olduğu görülmüştür. Bu farklılık Eğitim Fakültesi mezunu öğretmenlerin lisans öğrenimleri sırasında teknoloji destekli eğitim faaliyetlerine yönelik daha fazla ders almış olmalarından veya Teknik Meslek branşlarındaki öğretmenlerin çoğunlukla eğitim fakültesi mezunu olmalarından kaynaklanmış olabilir. Öğretmenlerin eğitim düzeylerine ve mezunu oldukları fakülte türlerine göre elde edilen bulgular birlikte değerlendirildiğinde, öğretmenlerin TYT'leri üzerinde eğitim düzeylerinden ziyade almış oldukları eğitimlerin içeriğinin daha belirleyici olduğu söylenebilir.

Araştırmada öğretmenlerin çoğunluğunun hizmet öncesinde üniversitede veya öğretmenliği sürecinde hizmet içi eğitim bünyesinde, derslerinde teknoloji kullanımı hakkında eğitim aldığı anlaşılmıştır. Fakat öğretmenlerin \%31'i gibi önemli bir kısmının (120 kişi) teknoloji kullanımı hakkında herhangi bir eğitim almadığını ifade etmiş olması dikkat çekicidir. Ayrıca öğretmenlerin TYT'leri derslerinde teknoloji kullanımı hakkında eğitim almış olmalarına göre incelendiğinde beklenenin 
ve daha önceki çalışmaların aksine (Tezci, 2010) herhangi bir anlamlı farklılığa rastlanmamış olması da dikkati çeken diğer bir durumdur. Aslında FATïH Projesi'yle ortaöğretim öğretmenleri başta olmak üzere bütün öğretmenlere yönelik hizmet içi eğitimler düzenlenmiştir. Bu bağlamda söz konusu bulgular proje kapsamında düzenlenen hizmet içi eğitimlerin hedeflenen yaygınlığa ve etkiye ulaşmadığını işaret ediyor olabilir. Nitekim öğretmenlerin \%18'i gibi azımsanmayacak bir kısmının (68 kişi) derslerinde teknolojik araçlardan ya hiç yararlanmiyor ya da nadiren yararlanıyor olması ve bu bağlamda özellikle "teknolojik araçların eğitim alanında kullanılmama durumu" faktöründe teknolojik araçlar kullanmayan öğretmenler aleyhine gözlemlenen anlamlı farklılık bu çıkarımı destekler niteliktedir. Çünkü öğretmenlerin söz konusu faktörden düşük puan alımış olmaları eğitimde teknoloji kullanımını gereksiz ve zaman alıcı buldukları, öğrenciler açısından motive edici bir yanının olmadığını düşündükleri anlamına gelmektedir. Daha önceki çalışmalarda FATIH Projesi kapsamında düzenlenen hizmet içi eğitimlerin öğretmenlerin teknoloji kullanımına yönelik kaygıları, olumsuz görüşleri ve ön yargıları gibi içsel engelleri gidermede yetersiz kaldığının ifade edilmiş olması da (Ardıç ve İşleyen, 2017; Keleş, Öksüz ve Bahçekapıll, 2013; Keleş ve Turan, 2015) bu sonucu destekler niteliktedir.

Öğretmenlerin TYT'leri derslerinde kullandıkları teknolojik araç çeşitliliği yönünden incelendiğinde ölçek genelinde ve nerdeyse ölçeğin bütün faktörlerinde derslerinde birden fazla teknolojik araç kullanan öğretmenler lehine gözlemlenen anlamlı farklıklar dikkat çekmektedir. Özellikle ölçeğin birinci, ikinci faktörlerinde ve genelinde gözlemlenen etki büyükleri, derslerde kullanılan teknolojik araç çeşitliğinin öğretmenlerin TYT’leri üzerinde olumlu etkisi olduğu şeklinde yorumlanabilir. Burada dikkat çeken diğer bir durum ise derslerinde sadece bir tane teknolojik araç kullanan öğretmenlerin TYT'lerinin teknolojiden yararlanmayan öğretmenlerden anlamlı bir farkla ayrışmamasıdır. Öğretmenlerin büyük çoğunluğunun (201 kişi \%53.17) derslerinde sadece akıllı tahtadan yararlandıkları dikkate alındığında bunun tek başına öğretmenlerin TYT'leri üzerinde anlamlı bir etki yaratmadığı söylenebilir. Bu durum söz konusu öğretmenlerin akıllı tahtayı geleneksel yazı tahtası gibi alışılmış şekilde kullanıyor olmalarından kaynaklanabilir. Nitekim öğretmenlerin derslerinde ağırlıklı olarak sadece notlarını yansıtmaya yarayan, öğrenci etkileşimine izin vermeyen PDF okuyucu (240 kişi \%63.5) veya MS Word tarzı kelime işlemcisi (143 kişi \%37.8) programlarını kullanıyor olmaları bu çıkarımı destekler niteliktedir. Öte yandan öğretmenlerin TYT'leri kullandıkları bilgisayar programı çeşitliliği yönünden incelendiğinde çoklu program kullanımın kayda değer düzeyde anlamlı farklılık yarattı̆̆ söylenebilir. Bu durum etki büyüklükleri yönünden ele alındığında birinci, dördüncü faktörler ve özellikle TYTÖ geneli tutumlar ön plana çıkmaktadır. Bu bağlamda derslerde kullanılan bilgisayar programı çeşitliliğinin öğretmenlerin TYT'leri üzerinde orta düzeyde olumlu etkiye sahip olduğu söylenebilir.

Araştırmada elde edilen sonuçlar bütün olarak değerlendirildiğinde öğretmenlerin TYT'lerinin "olumlu" düzeyde olmasının derslerinde teknolojiden yararlanmalarına pozitif yönde etkisi olduğu söylenebilir. Daha önceki çalısmalarda da öğretmenlerin teknolojik ve pedagojik yeterliliklerinin geliştirilmesinde TYT'nin olumlu etkisinin olduğu sonuçlarına varılmış olması bu çıkarımı destekler 
niteliktedir (Albayrak-Sarı vd., 2016; Buabeng-Andoh, 2012; Çelik ve Yeşilyurt, 2013; Kalemoğlu Varol, 2015; Yulisman vd., 2019). Öte yandan öğretmenlerin çoğunluğunun derslerinde sadece akıllı tahtadan yararlandığı, bu süreçte öğrencilerin etkileşime girebileceği donanım ve yazılımları kullanmadıkları anlaşılmaktadır. Bu bağlamda ortaöğretim öğretmenlerinin aldıkları eğitimlerin derslerinde teknolojik araçları kullanma şekilleri üzerinde istenen düzeyde bir etki yaratmadığı söylenebilir. Ölçek skorlarında gözlemlenen anlamlı farklılıklar ve etki büyüklükleri birlikte ele alındığında "Teknolojik araçların eğitim alanında kullanılmama durumu", "Teknolojik araçların eğitim alanında kullanılma durumu" ve "Teknolojik araçların kullanımının öğretilmesi" faktörlerinde derslerinde çoklu teknolojik araç ve bilgisayar programı kullanan öğretmenler lehine olan farklılıklar öne çıkmaktadır. Yani ilgili öğretmenlerin, eğitim-öğretim faaliyetlerinde teknoloji kullanımının gerekli ve önemli olduğu, bu faaliyetlerin öğretim çıtılarına katkı sağlayacağı, hem öğretmen yetiştirme programlarında öğretmen adaylarına hem de hizmet içi eğitim bünyesinde öğretmenlere teknoloji kullanımı hakkında eğitimler verilmesi gerektiği yönünde olumlu tutuma sahip oldukları söylenebilir. Bu bağlamda öğretmenlere ve öğretmen adaylarına tek bir teknolojik aracın teknik özelliklerinin öğretilmesinden ziyade, öğretim faaliyetlerinde öğrencileri de sürece dahil edebilecekleri farklı teknolojik araçlar ve bilgisayar programları hakkında uygulamalı eğitimler verilmesi önerilebilir. Bu eğitimler sayesinde öğretmenlerin derslerinde öğrencilerini de sürece aktif olarak dahil ettikleri teknoloji uygulamaları gerçekleştirmeleri sağlanabilir. Ayrıca öğretmenlerin demografik bilgileri üzerinden varılan sonuçlar doğrultusunda, düzenlenecek olan hizmet içi eğitimlerde öğretmenlerin hizmet sürelerinden ziyade yaşlarının dikkate alınmasının daha uygun olacağı söylenebilir. Bu doğrultuda hizmet içi eğitim faaliyetleri planlanırken; öğretmenleri yaşlarına göre gruplandırarak bu grupların gereksinimlerinin belirlenmesi ve ilk etapta 40 yaş üstü öğretmenlere öncelik verilmesi önerilebilir. Benzer şekilde hizmet içi eğitim faaliyetlerin planlanması aşamasında öğretmenlerin branşlarının ve görev yaptıkları okul türlerinin de dikkate alınması faydalı olabilir. $\mathrm{Bu}$ bağlamda öğretmenlerin branşlarına özgü gereksinimlerinin belirlenmesi adına ilgili alanın eğitimine yönelik teknoloji destekli sınıf uygulamalarının incelendiği farklı çalışmalar gerçekleştirilebilir. Araştırmadan elde edilen sonuçlar doğrultusunda, gerçekleştirilecek çalışmalarda ve hizmet içi eğitim faaliyetlerinde anadolu ve fen liselerinde görev yapan kültür dersleri (matematik, fizik, tarih, coğrafya v.b.) branşlarındaki öğretmenlere öncelik verilmesi önerilebilir.

\section{Kaynakça}

Albayrak Sari, A., Canbazoglu Bilici, S., Baran, E. ve Ozbay, U. (2016). Farkl1 branşlardaki öğretmenlerin teknolojik pedagojik alan bilgisi (TPAB) yeterlikleri ile bilgi ve iletişim teknolojilerine yönelik tutumları arasındaki ilişkinin incelenmesi. Eğitim Teknolojisi Kuram ve Uygulama, 6(1), 1-21. https:// doi.org/10.17943/etku.11643

Ardıç, M. A. ve İşleyen, T. (2017). High School Mathematics Teachers' Views On Computer-Assisted Mathematics Instruction Through Computer Algebra Systems in Turkey. European Journal of Education Studies, [S.1.], mar. 2017. Doi: 10.5281/zenodo.345626. 
Bahar, H. H., İçli, H. H. ve Gülaçtı, F. (2010). Ortaöğretim öğretmenlerinin bilgisayar ve internet tutumlarının incelenmesi (Erzincan örneği). Milli Ĕ̆itim Dergisi, 40(188), 50-67.

Birkollu, S. S., Yucesoy, Y., Baglama, B. ve Kanbul, S. (2017). Investigating the attitudes of pre-service teachers towards technology based on various variables. TEM Journal, 6(3), 578.

Birgin, O., Uzun, K. ve Akar, S. G. M. (2020). Investigation of Turkish mathematics teachers' proficiency perceptions in using information and communication technologies in teaching. Education and Information Technologies, 25(1), 487507. https:/ / doi.org/10.1007/s10639-019-09977-1

Bisgin, H. (2014). Analyzing the attitudes of physical education and sport teachers towards technology. The Anthropologist, 18(3), 761-764.

https:// doi.org/10.1080/09720073.2014.11891607

Buabeng-Andoh, C. (2012). Factors influencing teachersâ adoption and integration of information and communication technology into teaching: A review of the literature. International Journal of Education and Development using ICT, 8(1), 136-155.

Büyüköztürk, Ş., K1lıç Çakmak, E., Akgün, Ö. E., Karadeniz, Ş. ve Demirel, F. (2010). Bilimsel araştırma yöntemleri (7. Bask1). Ankara: Pegem Yayıncılık.

Cai, Z., Fan, X. and Du, J. (2017). Gender and attitudes toward technology use: A meta-analysis. Computers E Education, 105, 1-13. https:// doi.org/10.1016/j.compedu.2016.11.003

Cattagni, A. and Farris, E. (2001).Internet access in U.S. public schools and classrooms: 1994-2000 (NCES 2001-071). U.S. Department of Education. Washington, DC: National Center for Education Statistics.

Çakır, R. ve Oktay, S. (2013). Bilgi toplumu olma yolunda öğretmenlerin teknoloji Kullanımları. Endüstriyel Sanatlar Eğitim Fakültesi Dergisi, 30, 35-54.

Çelik, V. and Yesilyurt, E. (2013). Attitudes to technology, perceived computer selfefficacy and computer anxiety as predictors of computer supported education. Computers $\mathcal{E}$ Education, 60(1), 148-158. https:// doi.org/10.1016/j.compedu.2012.06.008

Dursun, M., Tozoğlu, E., Bayraktar, G., Çingöz, B. and Tozoğlu, B. (2017). Attitudes of the Students at Physical Education (PE) Teaching and Sports Department towards Technology Use in Education. International Journal of Sport Culture and Science, 5(1), 11-19. https://doi.org/10.14486/IntJSCS639

Ertmer, P. A. (1999). Addressing first-and second-order barriers to change: Strategies for technology integration. Educational technology research and development, 47(4), 47-61. https:/ / doi.org/10.1007/BF02299597

Ertmer, P. A., Ottenbreit-Leftwich, A. T., Sadik, O., Sendurur, E. and Sendurur, P. (2012). Teacher beliefs and technology integration practices: A critical relationship. Computers E Education, 59, 423-435. https://doi.org/10.1016/j.compedu.2012.02.001

Fındıkoğlu, F., Alcı, B. and Karataş, H. (2015). The correlation between pre-service teachers' attitudes towards technology and achievement in material design course. The Anthropologist, 20(3), 744-753. https:// doi.org/10.1080/09720073.2015.11891781 
Field, A. (2009). Discovering statistics using SPSS (3. edt.). London: Sage

Fletcher, J.D. (2003). Does this stuff work? A review of technology used to teach. TeachKnowLogia, Knowledge Enterprise, Inc.

Göktas, Y., Gedik, N. and Baydas, O. (2013). Enablers and barriers to the use of ICT in primary schools in Turkey: A comparative study of 2005-2011. Computers $\mathcal{E}$ Education, 68, 211-222. https:// doi.org/10.1016/j.compedu.2013.05.002

İspir, E., Furkan, H. ve Çitil, M. (2007). Lise fen grubu öğretmenlerinin teknolojiye ilişkin tutumlar1-Kahramanmaraş örneği. Erzincan Üniversitesi Ĕ̆itim Fakültesi Dergisi, 9(1), 63-72.

Kağıtçıbaşı, Ç. (1999). Yeni insan ve insanlar sosyal psikolojiye giriş. İstanbul: Evrim Yayınevi.

Kalemoğlu Varol, Y. (2015). Predictive Power of Prospective Physical Education Teachers' Attitudes towards Educational Technologies for Their Technological Pedagogical Content Knowledge. International Journal of Progressive Education, 11(3), 7-19.

Kayalar, M. T. (2018).Examining pre-service teachers 'attitudes and interests in technology in terms of various variables. Journal of Social And Humanities Sciences Research (JSHSR), 5(27), 2753-2760.

Keleş, E. ve Turan, E. (2015). Öğretmenlerin fırsatları arttırma ve teknolojiyi iyileştirme hareketi (FATİH) hakkındaki görüşleri. Turkish Journal of Education, 4(2), 17-28.

Keleş, E., Öksüz, B. D. ve Bahçekapılı, T. (2013). Teknolojinin eğitimde kullanılmasına ilişkin öğretmen görüşleri: Fatih projesi örneği. Gaziantep Üniversitesi Sosyal Bilimler Dergisi, 12(2), 353-366.

MEB, (2020). Fırsatları Artırma ve Teknolojiyi İyileştirme Hareketi (FATİH) Projesi.http:/ / fatihprojesi.meb.gov.tr/en/index.html adresinden 17.02.2020 Tarihinde erişilmiştir.

Oskamp, S. and Schultz, P. W. (2005). Attitudes and Opinions. New Jersey: Lawrence Erlbaum Associates. https:// doi.org/10.4324/9781410611963

Ottenbreit-Leftwich, A., Liao, J. Y. C., Sadik, O. and Ertmer, P. (2018). Evolution of teachers' technology integration knowledge, beliefs, and practices: How can we support beginning teachers use of technology?. Journal of Research on Technology in Education, 50(4), 282-304. https:/ / doi.org/10.1080/15391523.2018.1487350

Paşa, S., Bolat, Y. ve Karataş, F. (2015). Kimya öğretmenliği öğrencilerinin bilişim teknolojilerine yönelik tutum ve görüşlerindeki değişimler: Chembıodraw uygulamas1. Journal of Computer and Education Research, 3(6), 71-98. https://doi.org/10.18009/jcer.02018

Prensky, M. (2001). Digital natives, digital immigrants. On the Horizon, 9(5), 1-6.

Şahin, M. C. ve Namlı, N. A. (2019). Öğretmen adaylarının eğitimde teknoloji kullanma tutumlarının incelenmesi. Türkiye Sosyal Araştırmalar Dergisi, 23(1), 95-112.

Şimşek, Ü. and Yıldırım, T. (2016). The attitudes and opinions of social studies teacher candidates on the usage of technology in education. Journal of Human Sciences, 13(1), 632-649. https:/ / doi.org/10.14687/ijhs.v13i1.3506 
Tezci, E. (2010). Attitudes and knowledge level of teachers in ICT use: The case of Turkish teachers. Journal of Human Sciences, 7(2), 19-44.

Üstün, A. ve Akman, E . (2015). Özel okul öğretmenlerinin eğitimde teknoloji kullanımına ilişkin tutum ve görüşleri (Samsun ili örneği). Journal of Educational Science, 3(4) , 94-103.

Yavuz, S. (2005). Developing a technology attitude scale for pre-service chemistry teachers. Turkish Online Journal of Educational Technology-TOJET, 4(1), 17-25.

Yıldırım, A. ve Şimşek, H. (2008). Sosyal bilimlerde nitel araştırma yöntemleri (7. Bask1). Ankara: Seçkin Yayıncılık.

Yulisman, H., Widodo, A., Riandi, R. and Nurina, C. I. E. (2019). Moderated effect of teachers' attitudes to the contribution of technology competencies on

TPACK. Jurnal Pendidikan Biologi Indonesia, 5(2), 185-196.

https://doi.org/10.22219/jpbi.v5i2.7818

\section{Summary}

\section{Introduction}

Examining the barriers encountered in the use of technology in education, it is understood that they fundamentally consist of two orders as external and internal. In short, barriers that aren't related to the teacher such as the lack of access to the hardware and software required in the teaching process, incompetent teaching plans, and lack of necessary technical, and administrative support are external obstacles. Whereas internal barriers can be summarized as the attitudes and beliefs of teachers towards themselves, as well as teaching and learning activities. It is emphasized that it is more difficult to overcome internal barriers to the use of technology in education than external barriers (Ertmer, 1999). As a matter of fact, it can be said that the external barriers faced by teachers have been overcome or are overcome by carrying out comprehensive activities in many countries similar to FATIH Project in Turkey for many years. However, many studies conducted in this process emphasize that internal barriers still have a decisive influence (Ertmer et al., 2012; Göktaş, Gedik \& Baydaş, 2013; Ottenbreit-Leftwich, Liao, Sadik \& Ertmer, 2018). In this context, internal barriers such as negative attitudes of teachers towards technology come to the fore. This study aims to investigate the attitudes of secondary education teachers' towards technology, as studies addressing this situation with a holistic perspective specifically for secondary teachers haven't been sufficiently in the literature.

\section{Method}

The screening model, which is one of the quantitative research methods, was utilized in the study. In the research, where the participants were determined on a voluntary basis using convenience sampling method, 378 secondary education teachers, who work in different branches of 22 high schools in 5 different types in Adryaman province, took part as participants. In the research, a form consisting of two sections was used as the data collection tool. The first section of the form includes questions related to the demographic information of the teachers, frequency of their using the technological tools in lessons, and the technological tools and computer software they utilize. The Scale of Attitude towards Technology (SATT) developed by Yavuz 
(2005) takes part in the second section of the form. As a five-point Likert scale, SATT consists of five factors and 19 items. Cronbach's Alpha reliability coefficient of SATT was calculated as 0.83 . Single Factor Multivariate analysis of variance (MANOVA) was used in the analysis of the data obtained in the study. An analysis of variance (ANOVA) was applied for each dependent variable as a follow-up test in the research. Moreover, Hochberg's GT2 test was utilized as a post-hoc test.

\section{Results}

In the study, it was understood that the attitudes of secondary education teachers towards technology were "positive" in the scale and in all of its factors. Furthermore, it was also seen that the attitudes of secondary education teachers towards technology do not differ significantly based on their gender, duration of service, education levels, and status of previous education on the use of technology in their lessons. On the other hand, it was understood that the attitudes of secondary education teachers towards technology differ significantly across the scale or various factors based on their ages, branches, the type of school they work at and the faculty they graduated from, the frequency of using technological tools in their courses, and the variety of technological tools or computer software used in such courses.

\section{Discussion}

When the results obtained in the research are evaluated as a whole, it can be said that the "positive" attitudes of teachers towards technology have a positive effect on their use of technology in their lessons. The fact that attitudes towards technology having been established to have a positive impact on the development of technological and pedagogical competencies of teachers in previous studies supports this conclusion (Albayrak-Sarı et al., 2016; Buabeng-Andoh, 2012; Çelik \& Yeşilyurt, 2013; Kalemoğlu Varol, 2015; Yulisman et all., 2019). On the other hand, it is seen that the majority of teachers use only smart boards in their lessons, they do not make use of hardware and software that students can interact with. In this context, it can be said that a significant number of secondary education teachers education do not have the desired impact on the way they benefit from technological tools in their lessons. Examining the significant differences and effect sizes observed in the scale scores together for the factors "Not using technological tools in the field of education," "Using technological tools in the field of education", and "Teaching the use of technological tools", it is seen that the differences emerge in favor of the teachers, who use multiple technological tools and computer software in their lessons. In other words, it can be argued that the teachers in question had positive attitudes toward the facts that using technology in education was necessary and important, that these activities would contribute to the learning outcomes, and that teachers should be trained on the use of technology in both teacher training programs and in-service training.

\section{Pedagogical Implications}

In this context, rather than teaching the technical characteristics of a single technological tool to teachers and teacher candidates, it may be recommended to provide practical training on different technological tools and computer software, to which teachers can have their students participate in the teaching activities. These 
training programs can ensure that teachers perform technology applications in their lessons, where their students could get actively involved. In addition, in line with the results obtained from the demographic information of the teachers, it can be said that it would be more appropriate to take into consideration the age of the teachers rather than the service period in the in-service training to be held. Similarly, it may be beneficial to consider the branches of teachers and the types of schools they work at during the planning of in-service training activities. In this context, in order to determine the specific needs of teachers, different studies can be carried out, in which technologically supported classroom practices regarding the education of the related field are examined.

\section{Araştırmanın Etik Taahhüt Metni}

Yapılan bu çalışmada bilimsel, etik ve alıntı kurallarına uyulduğu; toplanan veriler üzerinde herhangi bir tahrifatın yapılmadığı, karşılaşılacak tüm etik ihlallerde "Cumhuriyet Uluslararası Eğitim Dergisi ve Editörünün" hiçbir sorumluluğunun olmadığı, tüm sorumluluğun Sorumlu Yazara ait olduğu ve bu çalışmanın herhangi başka bir akademik yayın ortamına değerlendirme için gönderilmemiş olduğu sorumlu yazar tarafından taahhüt edilmiştir.

\section{Yazar Bilgileri/Authors' Biodata}

Mehmet Alper ARDIÇ, Atatürk Üniversitesi, Kazım Karabekir Eğitim Fakültesi matematik öğretmenliği bölümü mezunudur. Doktorasını Atatürk Üniversitesi Eğitim Bilimleri Enstitüsünde matematik eğitimi alanında yapmıştır. Adıyaman Üniversitesinde araştırma görevlisi doktor olarak çalışmaktadır.

Mehmet Alper Ardıç, Mehmet Alper ARDIÇ is a graduate of Atatürk University Kazım Karabekir Faculty of Education, Department of Mathematics Teaching. He completed his $\mathrm{PhD}$ in the field of mathematics education at Atatürk University, Institute of Educational Sciences. He works as a research assistant doctor at Adiyaman University. 